\title{
Burning questions: investigations using field experimentation of different patterns of change to bone in accidental vs deliberate burning scenarios
}

Article

Accepted Version

Creative Commons: Attribution-Noncommercial-No Derivative Works 4.0

Carroll, E. L. and Smith, M. (2018) Burning questions: investigations using field experimentation of different patterns of change to bone in accidental vs deliberate burning scenarios. Journal of Archaeological Science: Reports, 20. pp. 952-963. ISSN 2352-409X doi:

https://doi.org/10.1016/j.jasrep.2018.02.001 Available at https://centaur.reading.ac.uk/75512/

It is advisable to refer to the publisher's version if you intend to cite from the work. See Guidance on citing.

To link to this article DOI: http://dx.doi.org/10.1016/j.jasrep.2018.02.001

Publisher: Elsevier

All outputs in CentAUR are protected by Intellectual Property Rights law, including copyright law. Copyright and IPR is retained by the creators or other copyright holders. Terms and conditions for use of this material are defined in the End User Agreement. 


\section{www.reading.ac.uk/centaur}

\section{CentAUR}

Central Archive at the University of Reading

Reading's research outputs online 
1 Title: Burning questions: Investigations using field experimentation of different patterns of 2 change to bone in accidental vs deliberate burning scenarios.

3 First Author: Emily Louise Carroll. Bournemouth University; University of Reading.

4 Second Author: Martin Smith.

5 Affiliation Address: Bournemouth University, Talbot Campus, Fern Barrow, Poole, Dorset $6 \mathrm{BH} 12$ 5BB.

7 Corresponding Author: Emily Carroll. ${ }^{1}$ e.I.carroll@pgr.reading.ac.uk

8

9

10

11

12

13

14

15

16

17

18

19

20

21

22

23

24

25

${ }^{1}$ Present Address: Room 126, Wager Building, Department of Archaeology, University of Reading, PO Box 217, Reading, Berkshire, RG6 6AH, United Kingdom. 
27 Experimental research into thermal alterations to bone has tended to be carried out under laboratory conditions, where different burning scenarios are simulated to reconstruct the respective heat-induced changes in bone. While this approach has greatly advanced this field of research, very little open-air field experimentation has been conducted and consequently documented. The current paper presents the results of the first study to utilise field experimentation to examine the heat-induced alterations that occur in bone when subjected to two different firing conditions. This experiment contrasted a reconstruction of a funeral pyre with a simulated house fire in order to explore differences in the effects of accidental and deliberate burning scenarios on bone. Both advantages and problems faced are discussed with regards to the methodological approach used to document and analyse the resultant burnt bone; leading to recommendations for future research. The burned bone assemblage from the accidental fire displayed uneven burning, with an extensive spectrum of colour alteration. Bone fragments recovered from the funeral pyre however showed distinctly uniform thermal changes, with minimal variation. This research demonstrates the value of field experimentation in the analysis of burned bone from both archaeological and forensic contexts. Insight into both ancient and modern households and their subjectivity to domestic fires, as well as the social and ritual implications of past cremation funerals are considered. It is concluded that future research would greatly benefit from employing a similar mode of investigation, in conjunction with laboratory experimentation.

\section{Key words}

Burned bone; Bioarchaeology; Experimental Archaeology; Heat-induced alterations; Cremation pyre; Accidental fire.

\section{Introduction}

Understanding the thermal decomposition of bone is essential for reconstructing the effect of fire on human remains, in both forensic and archaeological contexts (Symes et al. 2015; Gonçalves et al. 2011; Thompson et al. 2016; Ubelaker 2009). Research in this area has advanced significantly over the past three decades (Collier 1996; McKinley 2015) with studies mostly employing laboratory experimentation to examine the macroscopic and microscopic heat-induced $(\mathrm{H}-\mathrm{I})$ alterations that occur in burned bone, how they correlate to the temperature and duration of combustion and what techniques best suit their analysis (Ellingham et al. 2015a; Ellingham et al. 2015b; Gonçalves et al. 2011; Gonçalves et al. 2015b; Piga et al. 2009; Thompson et al. 2009; Thompson et al. 2013; Snoeck et al. 2016). 
62 Despite the expanse of research in this field, only a handful of published experiments have been conducted outdoors in open air environments (Downes 1999; Jonuks and Konsa 2007; Marshall 2011; McKinley 1997; Silva 2015). These have tended to focus on reconstructing the collapse of the pyre or dwelling, the spread of material in the ground deposit following cremation, or the osteological assessment of the burnt bone. As such, the current literature lacks critical documentation and evaluation of this manner of experimentation in general, with specific areas that might benefit from further study including comparisons between different styles of 'open-air' burning and also the $\mathrm{H}$-I changes in the bone recovered.

The current paper discusses the results of a pilot study where two deer carcasses were subjected to two differently constructed experimental fires, in order to study macroscopic changes to bone subject to thermal alteration in differing circumstances. The first was a structured funeral pyre, the other a simulated accidental indoor fire using a metal shipping container to represent a generic domestic structure. There were three principle aims to the investigation; firstly, to establish a protocol on how to conduct, record and interpret open-air experimental fires; secondly to document both experiments; thirdly, to investigate how bone responds to opposing firing conditions, one that is managed and one that is left to burn out without ongoing intervention, by recording multiple $\mathrm{H}-\mathrm{I}$ modifications in the remnant burnt bone.

\section{1. $\mathrm{H}-\mathrm{I}$ alterations in bone}

Certainly, the most widely documented and well-studied macroscopic alteration that occurs to bone when subject to extreme heat is colour change (Delvin and Herrmann 2015). Research has found that a skeletal element will pass through a sequential spectrum of chromatic alteration, from yellowish to white, which is caused by the combustion of its organic and inorganic components and is subject to oxygen availability (Fig. 1) (Reidsma et al. 2016; Ubelaker 2009; Ullinger et al. 2015). When bone is first subjected to heat it changes from its normal ivory colour to brown and then black, caused by the combustion of both carbon and collagen. This is followed by grey which is induced by the polarization of organic compounds, and then white which is caused by the complete combustion of the bone's organic material and the fusion of bone mineral (Ellingham et al. 2015a). This sequence of colour change in bone is always consistent, however different researchers have reported varying temperatures at which these stages are achieved (Ellingham et al. 2015a). Colouration in burned skeletal remains can also be a consequence of staining from minerals within the burial environment or the melting of metal artefacts that are either worn or placed with the individual at the time of 
incineration (Brady 2006; Dupras and Shultz 2013). It is therefore essential to consider the wider context of the burned deposit as well as any extraneous inclusions prior to interpretation.
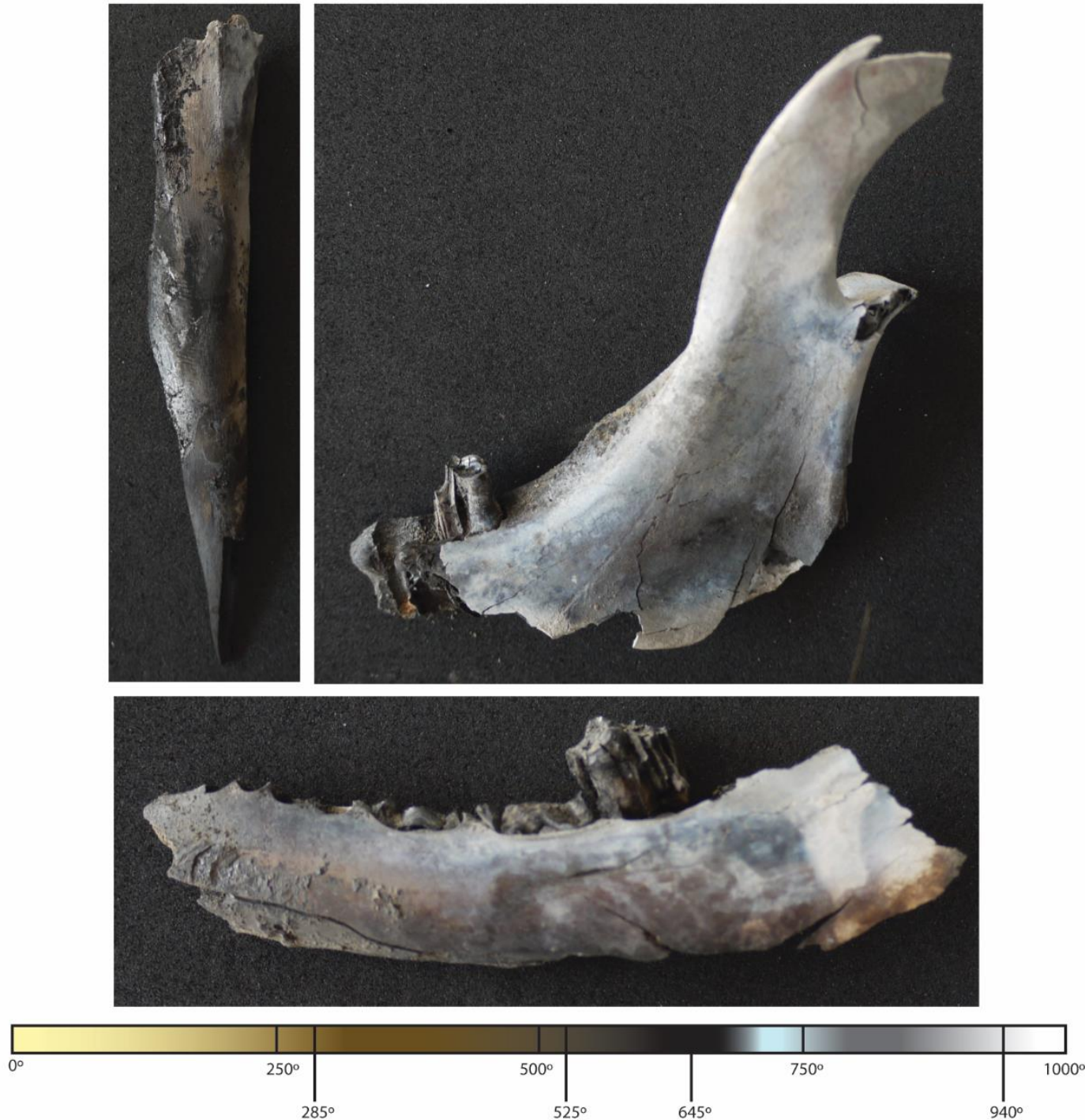

101

Fig. 1. Animal bone samples displaying the colour alteration that takes place when subject to extreme heat.

Further macroscopic $\mathrm{H}-\mathrm{I}$ alterations that have also been extensively researched include fracture patterning, warping, heat-induced size changes and weight loss (Buikstra and Swegle 1989; Gonçalves et al. 2011; Gonçalves et al. 2015a; Gonçalves et al. 2015b; Thompson et al. 2005). Recent laboratory experiments have found that fracture patterning and warping is associated with the preservation of collagen in bone, as well as recrystallization at the inorganic phase, and has allowed researchers to infer pre-burning conditions; namely, the burning of fleshed and dry bone (Gonçalves et al. 2015b; Vasserol et al. 2016). Examining heat induced size change and weight loss has been found to be useful for the analytical assessment of burnt bone. The former has been associated with the coalescence of mineral 
crystals (Gonçalves 2011), while the latter is caused by the evaporation of water, the combustion of organic compounds and the release of $\mathrm{CO}_{2}$ (Ellingham et al. 2015b).

On a microscopic level, the ultra-structural morphology of bone also changes when heated (Ellingham et al. 2015a; Piga et al. 2016; Ritchie 2006; Thompson et al. 2009). The diameter of osteons and Haversian canals within bone shrink, while the size and formation of crystallites, which are made of bone's inorganic component, increase when subjected to higher burning temperatures (Nelson 1992). Histomorphology has been successfully used to examine these microscopic changes in burnt bone, and has found these alterations to be a sensitive indicator of thermal decomposition (Squires et al. 2011). More recently, studies have experimented with reconstructing the crystallinity indices of burnt bone to infer burning temperatures, including low, medium and high (Thompson et al. 2009; Thompson et al. 2013). The $\mathrm{Cl}$ index has been found to be the most reliable representation of the crystallinity of burnt bone and has been applied in the analysis of cremated samples from the archaeological record (Thompson et al. 2016).

126

\subsection{Laboratory Experiments}

From the early 1950s experiments have artificially recreated various firing conditions in order to record the gross changes that bone undergoes (Baby 1954; Binford 1963; Shipman 1984). The study of burnt bone and the reconstruction of firing conditions owes a huge debt to the numerous laboratory studies that have been conducted over the last 30 years (Ellingham et al. 2015b; Ellingham et al. 2016; McKinley 2015). These efforts include heating bone samples in ovens, kilns or furnaces (for the most part gas or electric powered) and altering the temperature at set or shifting intervals (Collini et al. 2015; Ellingham et al. 2015a; Shipman et al. 1984). Despite this method producing the sort after $\mathrm{H}-\mathrm{I}$ alterations within the skeletal samples, temperature selection is often subject to the settings of the oven or kiln used in the study. As such the burning temperatures used vary across studies.

The above research has established that thermal decomposition of bone is caused by temperature increase, although variation in the temperature threshold at which the decomposition stages take place may occur due to the action of other factors. Taken together research in this area conducted over recent decades has led to the general acceptance of four stages of thermal decomposition taking place between c. $100-1000^{\circ}$, and producing characteristic H-I alterations (Mayne Correia 1997; Thompson 2005; Ellingham et al. 2015a). 
Duration of burning has also been used to examine the thermal alteration of bone since it was first considered as a firing condition by Baby (1954). Study has henceforth experimented with varying firing durations. Most recently, research has examined the influence of increasing firing durations at varying temperature settings to record microscopic alterations (Ellignham et al. 2015b). It was found that longer burning durations or slower heating rates increased the progression of thermal decomposition in bone, highlighting that $\mathrm{H}-\mathrm{I}$ alterations are subject to shifting burning durations.

Laboratory research has also experimented with samples of varying states of preservation. Thurman and Willmore (1982) first pointed out that criteria to distinguish between these different kinds of burnt bone did not exist, despite claims of their evident differentiation (Baby 1954; Buikistra and Swegle 1989; Binford 1963; Spennemann and Colley 1989; Vasserol et al. 2016; Whyte 2001). These investigations have proved useful in both the fields of archaeology and forensics for determining the condition of the skeletal remains prior to burning (Gonçalves et al. 2011; Gonçalves et al. 2015b). However, different studies have reported conflicting results (Baby 1954; Binford 1963; Etxeberria 1994 Whyte 2001).

Due to the ethical constraints surrounding the use of human remains within scientific research, as well as the facilities available for conducting these kinds of studies, laboratory experiments have tended to use disarticulated animal bones as human proxies (Shipman et al. 1984; Thompson et al. 2013). While animal remains are recognised as a sufficient alternative to human tissue in some kinds of forensic research, the burning of sections of femora or mandibles is not representative of the cremation of a complete cadaver, where the distribution of fatty tissue, body positioning, and muscle contraction can all have an effect on thermal decomposition (Dehann 2015). Studies have overcome this issue by attending cremations at modern crematoria and recording the $\mathrm{H}-\mathrm{I}$ alterations visible (Gonçalves et al. 2015a). This approach provides a rare opportunity for the researcher to witness the changes that occur to a cadaver as a result of extreme heat exposure.

\subsection{Field Experiments}

Open-air experimentation has been used to analyse the $\mathrm{H}-\mathrm{I}$ changes in burned bone, but comparatively less so then Laboratory work (Downes 1999; McKinley 2004; Silva 2015; Ubelaker 2009). This approach has mainly been used in the field of forensics as a means of investigating case studies involving burnt human remains, including fatal domestic fires, homicides and suicides (Pope et al. 2004; Poppa et al. 2011). The main intention of which is to reconstruct the sequence of events leading up to death, and primarily focusing on 
distinguishing between perimortem and postmortem trauma in burnt skeletal remains (Gruchy and Rogers 2002; Herrmann and Bennett 1999; Marciniak 2009). Animal bone proxies are usually burnt on specially built campfires or fire pits following the infliction of sharp or blunt force trauma. The outcome of which has led to considerable advances in the forensic understanding of perimortem events when thermal alteration is involved, often finding that fire is a secondary process used to try to cover-up or destroy evidence (Brickley, 2007; Salter 2008; Symes et al. 2015, 52-54; Symes et al. 2012, 349).

In archaeology, several field experiments examining cremation practices have reconstructed funeral pyres (Jonuks and Konsa 2007; McKinley 1997; Marshall 2011; Noy 2000). Experiments have typically involved burning a box pyre, which is a tiered wooden tower that has been described in various classical sources including the cremation of Patroclus and Hector (lliad book 23) (Marshall 2011). McKinley's recreation of a Bronze Age funeral pyre examined how long it would take for the thermal decomposition of a human body, represented by a sheep cadaver, to be achieved (1997). The progression of the pyre's collapse was also monitored as was the spatial distribution of the burnt remains within the ground deposit. Marshall (2011) more recently also recreated Bronze Age cremations, experimenting with both box pyres and ring pyres. This extensive study once again recorded the collapse of the pyre, and the condition of the pyre base, but also the taphonomic alteration of various bronze pyre goods, in order to gain better understanding into pyre side rituals and the dressing of the body prior to cremation. The study found that a body burnt on a funeral pyre, where the fuel was continually supplemented and a sufficient oxygen supply was available could still show evidence for uneven burning due to the cadaver's position.

Studies on a considerably smaller scale have also used funeral pyre experiments to examine the role of burnt animal bones in the burning process and to establish criteria for distinguishing them from burnt human bone (Whyte 2001). It was common practice in antiquity for animal remains to be placed on the pyre as a ritual offering, or represent the discarded remains of funerary feasting indicative of ritual activity. Studies including those by Whyte (2001) as well as Bond and Worley (2006) have provided considerable insight into the types of activities which produced cremated animal bone and what it can reveal about ancient cremation rituals. In modern forensic investigations, mixing non-human animal remains with human remains during the burning process has also been observed as a further strategy employed by perpetrators attempting to conceal a murder (Brickley 2007).

Other studies utilising field experiments to examine burnt bone include experimental house fires (Flamman 2004; Rasmussen and Grønnow 2004). This field of research developed out of excavations in Jutland where an unprecedented amount of burned down Iron Age dwellings 
217 have been unearthed (Rasmussen and Grønnow 2004). This approach was recently applied 218 in UK archaeology when a reconstructed Anglo-Saxon house burnt down in an accidental fire 219 at West-Stow, Suffolk (Tipper 2012). Research questions are numerous, including determining 220 the cause of the fire, determining the sequence of collapse, and reconstructing the body 221 position of recovered fire victims (Bankoff and Winter 1979; Flamman 2004; Rasmussen and

222 Grønnow 2004). These publications have greatly enhanced the archaeological understanding 223 of ancient domestic fire victims and have led to further osteological analysis of burnt human 224 remains recovered from ancient house fires (Harvig et al. 2015). However these observations 225 have not been compared to those of other fire scenarios including deliberate cremations.

\section{Materials}

Two European roe deer carcasses (Capreolus capreolus) were used as proxies in these experiments. Both individuals were culled as part of the humane management of deer herds in Dorset, ensuring concordance with the Animals Scientific Procedures Act (1986). The deer, one male and one female, were not defleshed or otherwise manipulated prior to the experiments, except for a single gunshot wound to the thorax $(0.308$ caliber, $10-20 \mathrm{~mm}$ soft tissue wound). This was to ensure the authenticity of each experiment and to avoid compromising the results obtained. The female deer was $0.95 \mathrm{~m}$ long, stood $1.02 \mathrm{~m}$ tall and weighed $20 \mathrm{Kg}$, while the male measured $1 \mathrm{~m}$ long, stood $1.04 \mathrm{~m}$ tall and weighed $25 \mathrm{Kg}$. It is noted that this difference in body size may influence the degree of thermal decomposition due to their varying body mass indices. The two specimens had been dead for three days prior to each experiment. They were stored in chest freezers and then thawed prior to each experiment to prevent decomposition.

\subsection{Accidental Fire}

The first scenario was intended to simulate the effects of an accidental fire occurring in a built structure. This part of the research was conducted at West Moors Fire Training Centre, Dorset on the $31^{\text {st }}$ of March 2014, under the direction of the Dorset Fire and Rescue Services. The latter regularly reproduce the circumstances of accidental fires in buildings using metal shipping containers as the latter permit re-use. The metal container used in the current experiment (Fig. 2) measured c. $5 \mathrm{~m}$ by c. $2.5 \mathrm{~m}$. The deer was positioned towards the entrance of the container and five sheets of chipboard $(40 \mathrm{Kg})$, seven wooden planks $(336 \mathrm{Kg})$, as well as tissue paper $(0.5 \mathrm{Kg})$ were placed at the back of the container away from the carcass; this fuel was used to ignite the fire. This material was not replaced once burned. The door of the shipping container was also left open to encourage a sufficient air supply. The placement of 
253 smoke inhalation. The temperature of the container was recorded as often as possible using

254 a non-contact digital LCD infrared thermometer and an infrared thermometer camera. This 255 approach did not allow the temperature of the carcass itself to be recorded, but the 256 temperature of the combustion from a safe distance. Previous research has used built-in 257 temperature gages to record temperature, yet as this experiment was conducted on location 258 alternative mobile devices were necessary (Ellingham et al. 2016). A handheld Panasonic 259 Lumix G1 52mm Camera and a Panasonic HC-X920 video camera were used to document 260 the experiment.

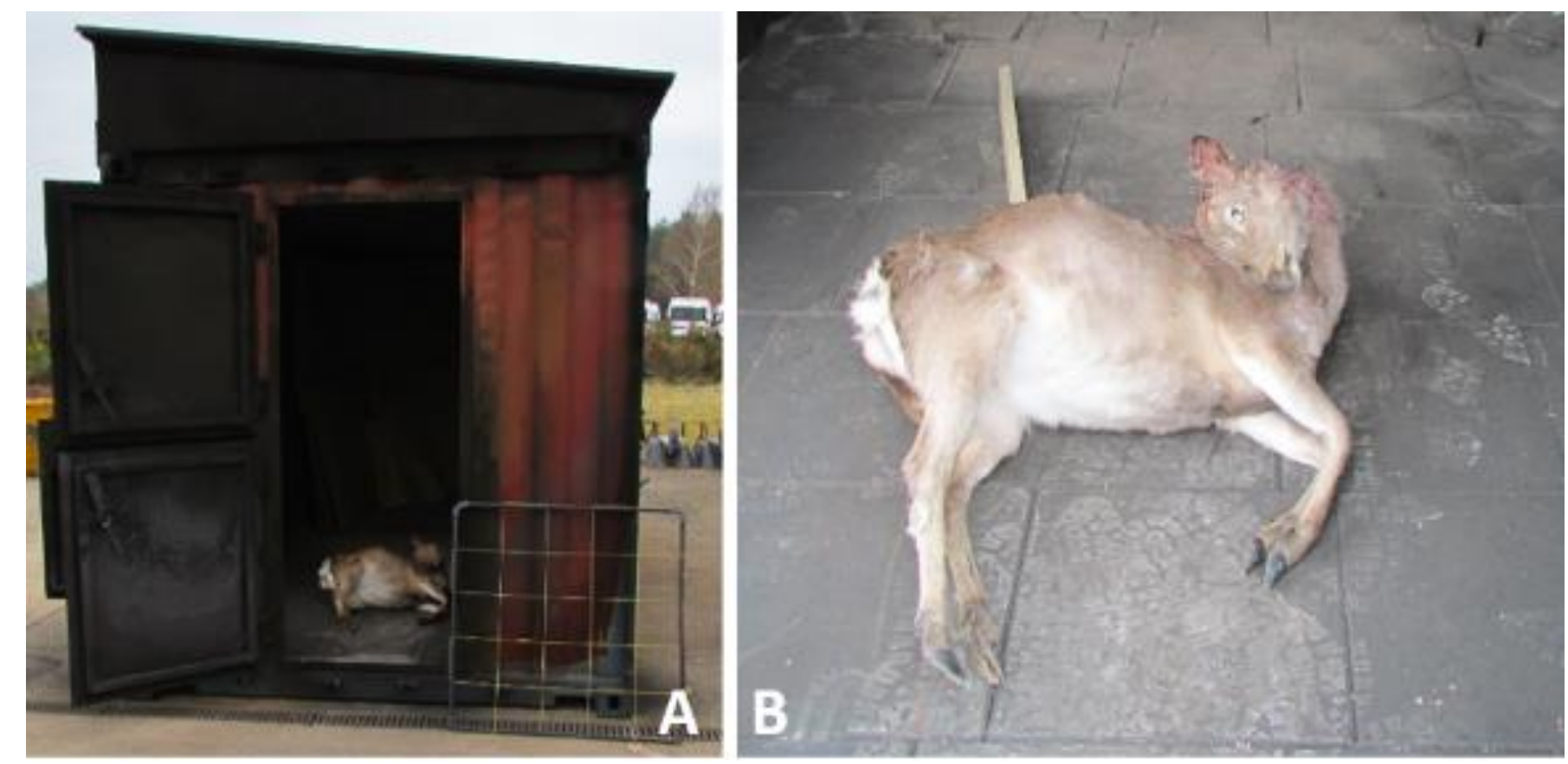

Fig. 2. A). The setup of the shipping container fire. B) The position of the deer carcass in the 264 shipping container.

\subsection{Funeral Pyre}

The first funeral pyre experiment was attempted on the $2^{\text {nd }}$ of July 2014, at Trigon Estate, Wareham Dorset. Unfortunately, as the wood provided was freshly cut green timber, the moisture content of the wood was too high and it was not possible to start the fire. The experiment was therefore postponed to the $4^{\text {th }}$ of July 2014. During this two day period, the carcass was stored in a shipping container on site, to stop it from being scavenged.

271 The pyre was situated in an open field, away from adjacent woodland (Fig. 3). The area in which it was placed had been cleared of any foliage that could exacerbate the combustion and the construction took the form of a ten-tiered, $2 \mathrm{~m}^{2}$ tower that stood at $1.4 \mathrm{~m}$ tall. The gridiron structure was chosen to encourage sufficient oxygen ventilation (McKinley 1997). The 
ascending layers were stuffed with hay $(3 \mathrm{Kg})$, and newspaper $(1 \mathrm{Kg})$ to ensure that the flash point would be high enough to achieve combustion (Marshall 2011). The deer was positioned on top of the pyre to guarantee direct heat exposure, and the fire's fuel load was maintained by the continual addition of logs, 27 halved juvenile birch $(1431 \mathrm{Kg})$, hay $(1 \mathrm{Kg})$ and newspaper $(1.5 \mathrm{Kg})$ until the pyre collapsed. The temperature of the container was recorded as often as possible using a non-contact digital LCD infrared thermometer and an infrared thermometer camera. Again, this approach did not allow the temperature of the carcass itself to be recorded, but the temperature of the combustion from a safe distance. A handheld Panasonic Lumix G1 52mm Camera and a Panasonic HC-X920 video camera was used to document the experiment.
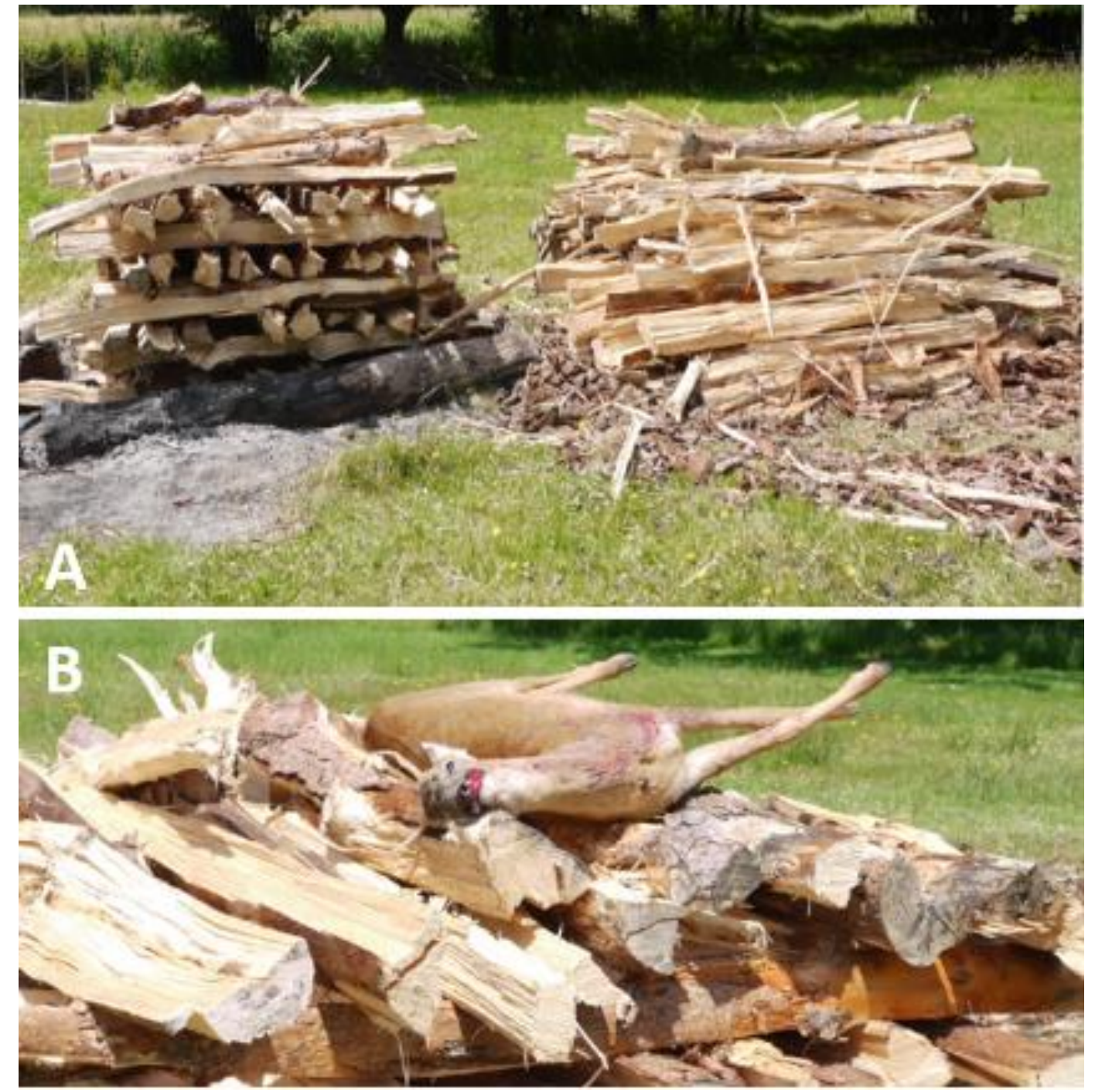

Fig. 3. A). The funeral pyre construction and the wood used to supplement the fuel load. B) The deer positioned on top of the pyre. 


\section{Methods}

The burnt bone from the shipping container fire was left overnight to cool before it was collected. The interior of the shipping container was gridded off, and the burnt bone was bagged up according to its grid reference. As the burnt bone was spread throughout the container, three grids were used to collect the material. This produced three sets of data. The leftover burnt bone from the funeral pyre was left for an hour and sprayed with water before collection; it was decided that the material should not be left overnight in case it was disturbed or scavenged. Again, the pyre site was gridded off and the burnt bone was bagged up according to its grid reference. The material from both experiments was then kept in plastic boxes and transported to the Bournemouth University Osteology Laboratory for analysis.

The burnt bone from the experiments was sorted in order to separate the thermally altered bone from any extraneous material.

\subsection{Degree of Burning}

The degree of burning was analysed using a 5 point visual scoring system adapted from Stiner et al. (1995) (Fig.4). This method ranks the progression of carbonization to calcination. At the bottom end of the scale, 1 represents the presence of soft tissue with minimal charring (blackening), while 5 denotes more than $50 \%$ calcination (whitening).
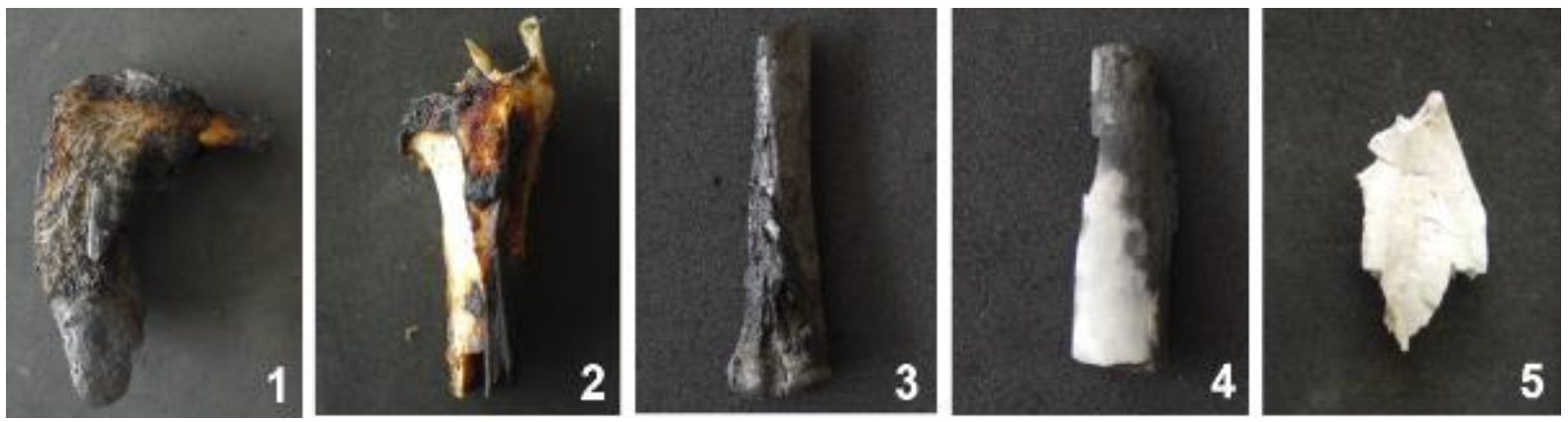

Fig. 4. Examples of different degrees of burning for each of the five scores. 1: Relatively unburned, still consisting of soft tissue. 2: Less than $50 \%$ carbonization. 3: More than $50 \%$ carbonization. 4: Less than $50 \%$ calcination. 5: More than $50 \%$ calcination. 


\subsection{Uniformity of Burning}

The uniformity of burning was measured using a 5 point visual scoring system adapted from Cain (2005) (Fig. 5). This technique identifies how many patterns of burning are visible within a single thermally altered bone fragment. A score of 1 represents uniform $\mathrm{H}-\mathrm{I}$ alteration, while 5 demonstrates variability.
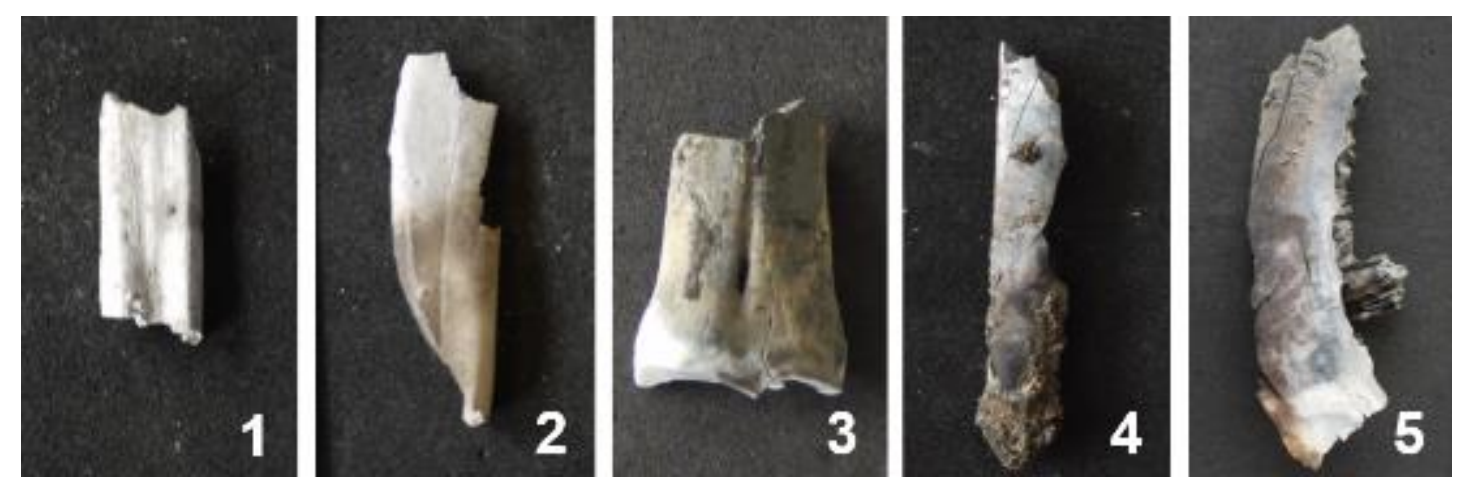

Fig. 5. Examples of the difference in the uniformity of burning for each of the five scores. 1 : Complete uniformity. 2: Two patterns of burning. 3: Three patterns of burning. 4: Four patterns of burning. 5. Five patterns of burning.

\subsection{Colour Change}

The colour of burnt bone was analysed using a 6 point visual scoring system, based on the sequential spectrum of colour change outlined in previous experimental research (Fig. 6) (Ellingham et al. 2015a; Mayne Correia 1997). A number was given to each thermally altered bone fragment that represented the colour observed. If multiple colours were visible within a single fragment then each pigmentation was scored and the median was calculated.
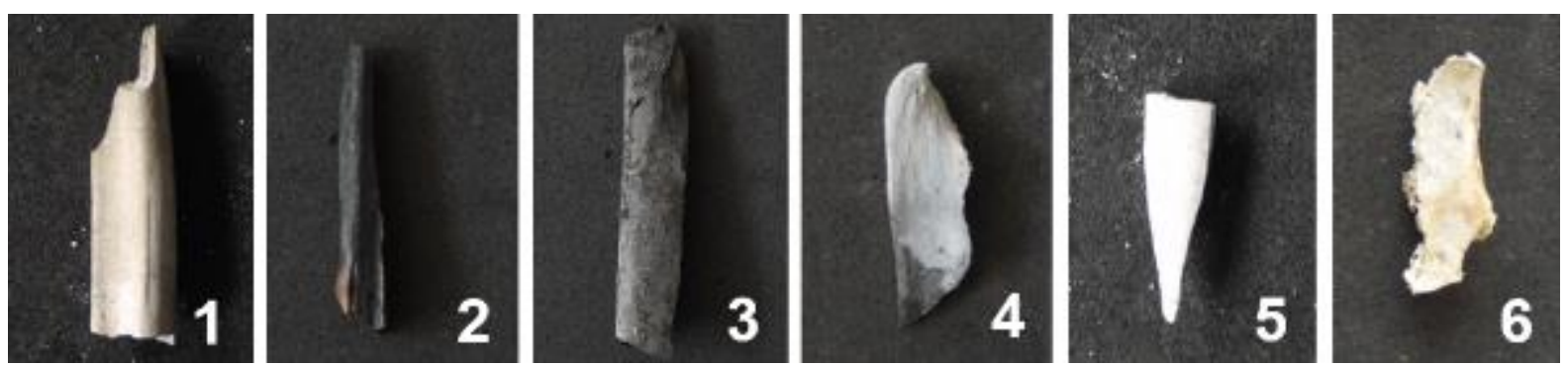

Fig. 6. Examples of the different colours for each of the five scores. 1: Brown. 2: Black. 3: Grey. 4: Blue. 5: White. 6: Orange. 


\subsection{Fracture Patterning}

Fracture patterning was analysed using a 5 point scoring system based on the criteria published by Buikstra and Swegle (1989) (Fig7). A number was assigned to each thermally altered bone fragment that represented the type of fracturing observed. Only surface fractures within the element were recorded, rather than the way in which each fragment had broken.

Consequently, if no fractures were present then a score of 0 was given.
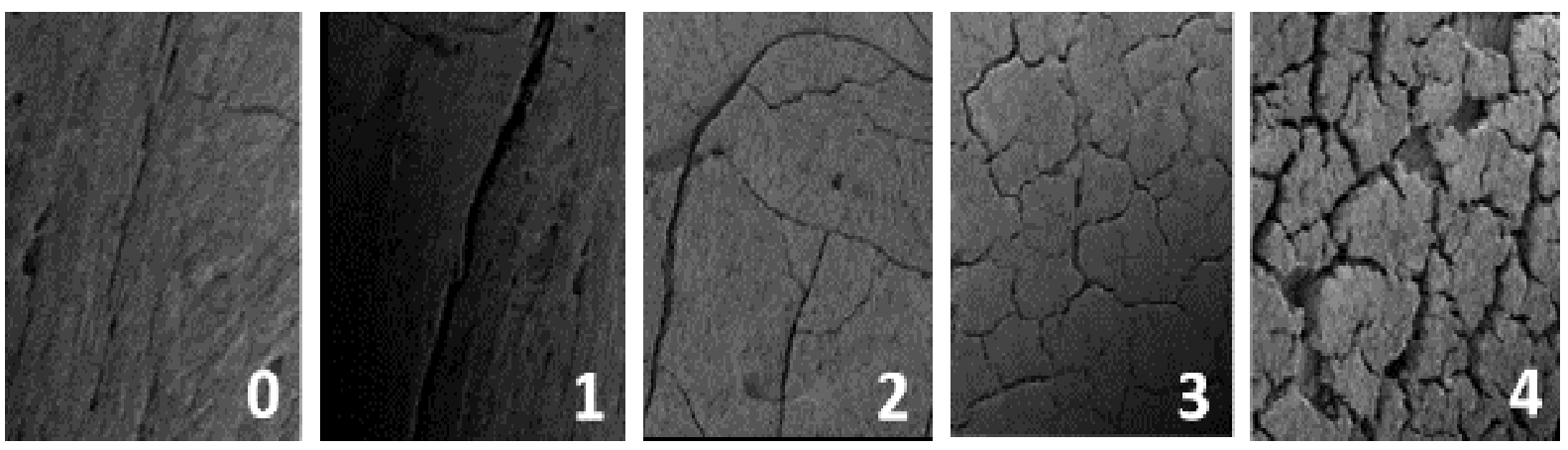

357

358

359

360

361

362

363

364

365

366

367

368

369

370

371

372

373

374

375

376

377

378

Fig. 7. Examples of the different fracture patterns for each of the five scores using SEM imagery. 0: No fracture patterning. 1: Longitudinal fracture. 2: Transverse fracture. 3 :

Polygonal fracture. 4: Exfoliated fracture.

\subsection{Weight}

The total weight of each assemblage was recorded using Fisherbrand PF-203 digital scales.

\subsection{Statistical Analysis}

Three statistical tests were applied in this investigation. First a Kruskal-Wallis H-Test (OneWay Analysis of Variance on ranked values) was conducted to pre-filter the data obtained from the shipping container fire, and to examine whether the data originates from the same distribution. This was necessary as three separate datasets were produced from this experiment all of which demonstrated different levels of $\mathrm{H}-\mathrm{I}$ changes; this test determined which dataset would be most appropriate to use (See Section 3.2). This particular test is more appropriate than that of a One-Way ANOVA of mean values as it examines ordinal information and does not assume a normal distribution of data. A Mann-Whitney $U$ test was then conducted to establish whether the thermal decomposition from the two experiments was statistically different. This test is designed to examine the variation of the median scores between two groups of non-specific distributions (Chalmer 1987; Field 2009). Even though this can be achieved by an Independent t-test, a Mann-Whitney $U$ test is better suited for this investigation as it is more robust when applied to data that do not conform to parametric assumptions (Sigvallius 1994). A student's t-test was then used to compare the mean weight 
of the two assemblages. All statistical tests were computed using the SPSS software package version 2014.

\section{Results}

The results from the Kruskal-Wallis H-Test (One-Way Analysis of Variance on ranked values) are presented in table 1. It is clear that the material from all three data sets differs significantly with regards to each variable analysed, demonstrating substantial intra-assemblage variation. It was recommended that as the material from grid 2 showed the highest degree of thermal exposure, it would be used in the analysis.

Table 1. Results from Kruskall-Wallis H-Test on the data from the shipping container fire.

\begin{tabular}{|c|c|c|c|c|c|}
\hline H-I Modification & $\begin{array}{c}\text { Grid } \\
\text { No. }\end{array}$ & Mean: & P - Value. & D.f. & Chi-Squ: \\
\hline \multirow{3}{*}{ Degree of burning } & 1 & 2.77 & .000 & 2 & 74.486 \\
\hline & 2 & 4.28 & .000 & 2 & 74.486 \\
\hline & 3 & 3.41 & .000 & 2 & 74.486 \\
\hline \multirow{3}{*}{ Uniformity of burning } & 1 & 2.39 & .001 & 2 & 13.675 \\
\hline & 2 & 2.64 & .001 & 2 & 13.675 \\
\hline & 3 & 2.98 & .001 & 2 & 13.675 \\
\hline \multirow{3}{*}{ Colour change } & 1 & 2.677 & .000 & 2 & 69.753 \\
\hline & 2 & 3.895 & .000 & 2 & 69.753 \\
\hline & 3 & 2.855 & .000 & 2 & 69.753 \\
\hline \multirow{3}{*}{ Fracture patterning } & 1 & 0.35 & .000 & 2 & 20.443 \\
\hline & 2 & 0.74 & .000 & 2 & 20.443 \\
\hline & 3 & 0.16 & .000 & 2 & 20.443 \\
\hline \multirow{3}{*}{ Weight } & 1 & 6.1 & .000 & 2 & 31.463 \\
\hline & 2 & 1.3384 & .000 & 2 & 31.463 \\
\hline & 3 & 2.8445 & .000 & 2 & 31.463 \\
\hline
\end{tabular}

\subsection{Accidental Fire - Shipping Container}

The experiment is documented in figure 9. The shipping container fire burnt out after 160 minutes. The range of temperatures recorded was $80-1000^{\circ} \mathrm{C}$, with extremely high temperatures recorded initially, followed by a sharp drop after the first half hour (Fig. 8). In this experiment, the door of the shipping container was the only channel of oxygen that fed the combustion and it is likely that a shortage of oxygen, after the initial supply inside the container was used up, also contributed to the sharp drop in temperature following the fire's flash point. 
396 An important point of note was that the deer began to combust before it was reached by the 397 flames. After twenty minutes the environment was so hot that the deer carcass self-ignited, 398 and the muscles contracted in both the front and hind legs causing them to rise and flex, taking 399 on a pugilistic position. By the end of the experiment, soft tissue remained on a large portion 400 of the torso, while the appendages were mostly calcinated.

401

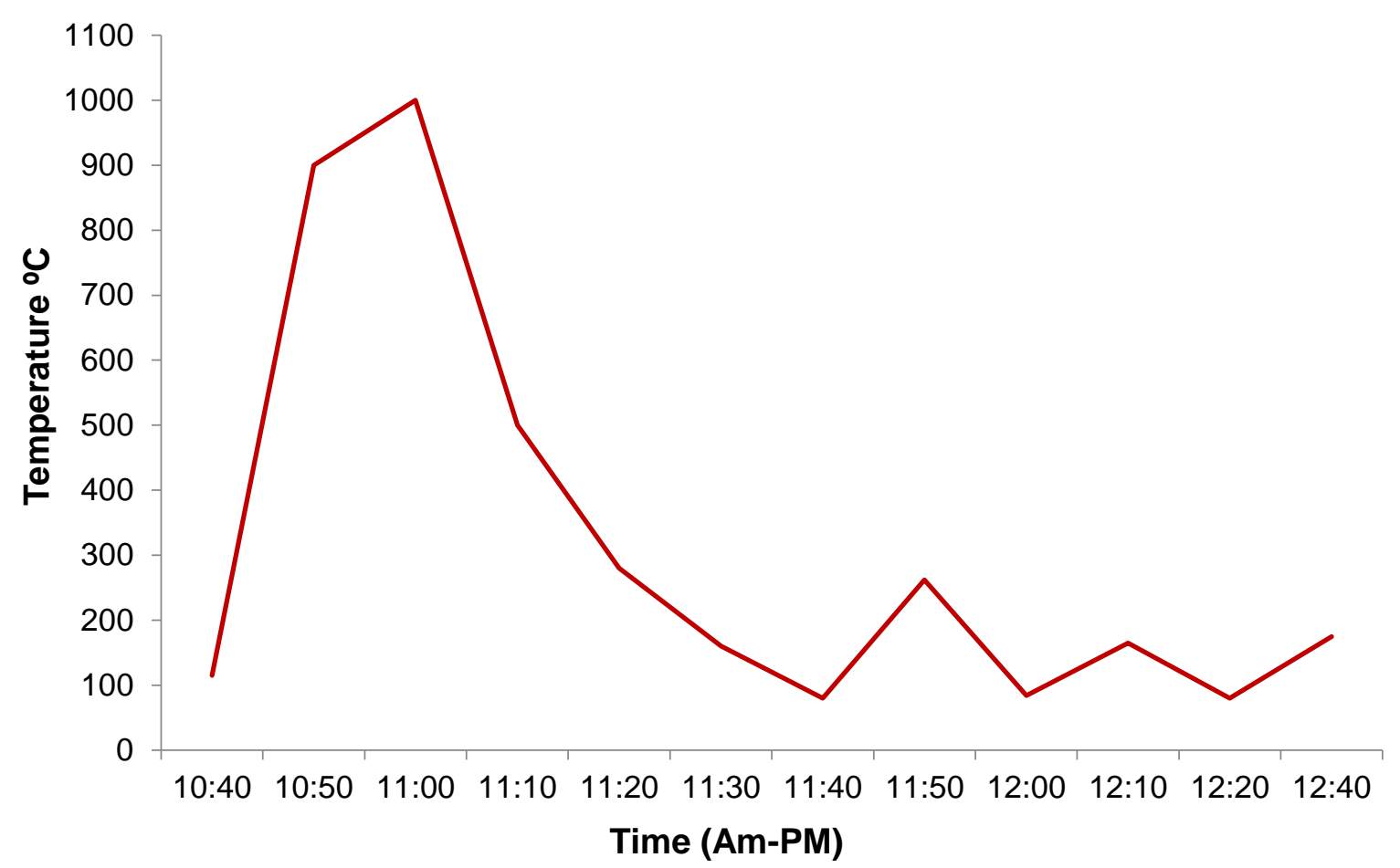

Fig. 8. The recorded temperatures of the shipping container fire over time.

404

405

406

407

408

409 

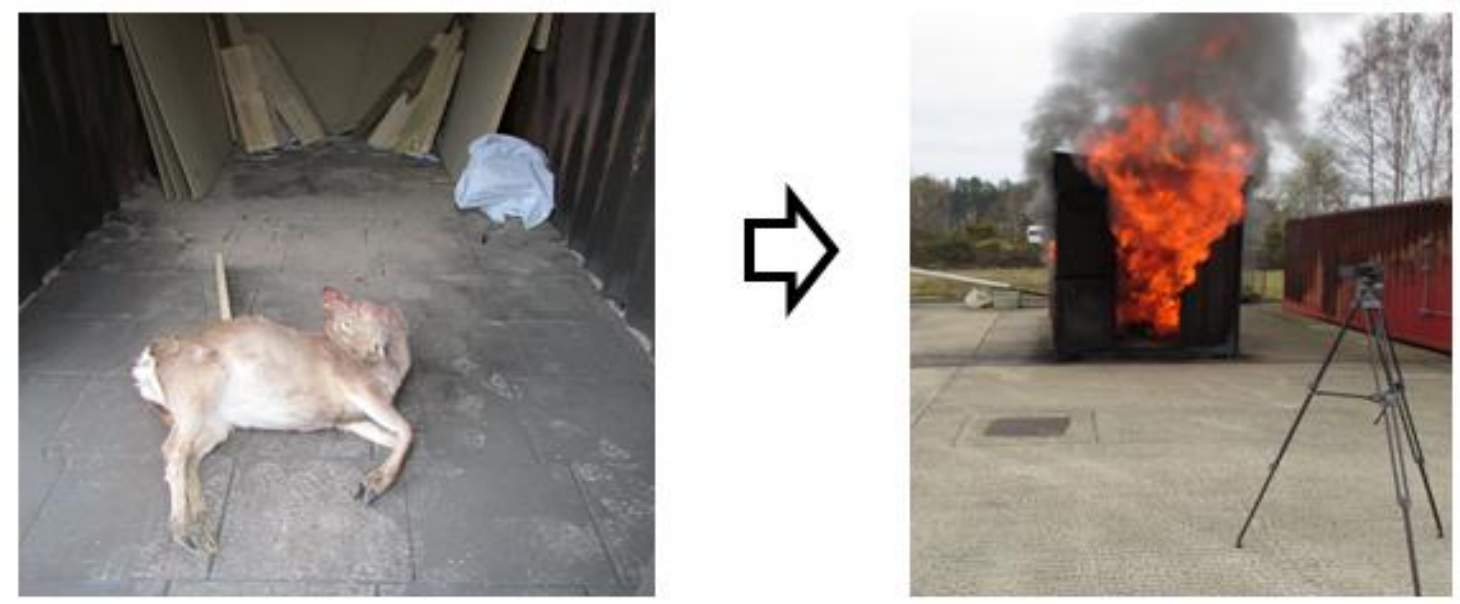

Set-up of carcass before combustion.
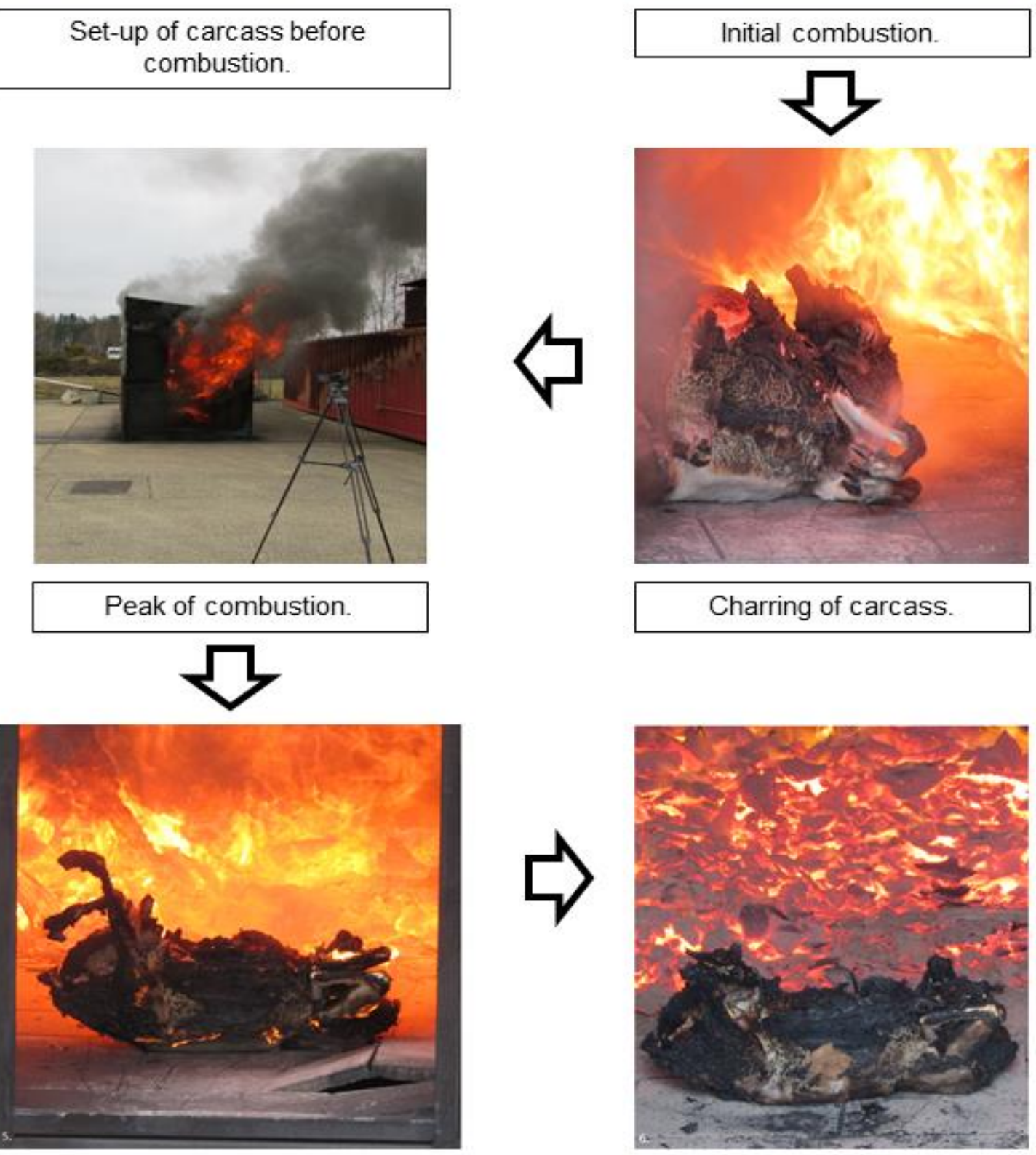

Flexing of carcass joints.

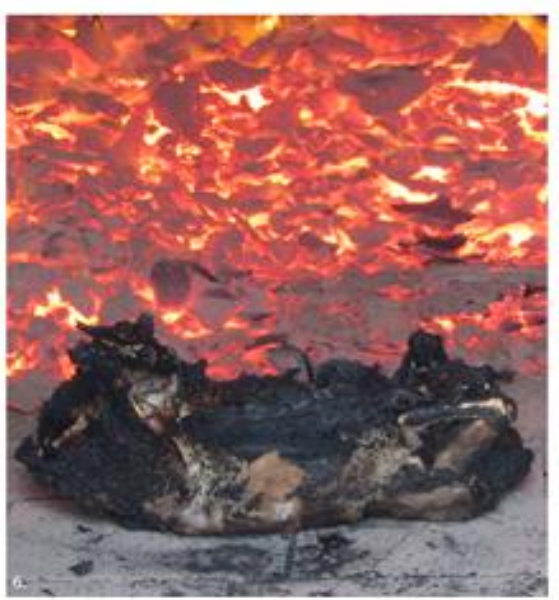

End of the experiment.

Fig. 9. Flow diagram documenting the shipping container experiment. 


\section{4.2. Funeral Pyre}

412 The experiment is documented in figure 11. The funeral pyre burned for a total of 210 minutes

413 and temperatures ranged from $166-553^{\circ} \mathrm{C}$ (Fig 10), demonstrating a continuum. In this 414 experiment it was noted that the strong northerly wind on the day of the experiment helped 415 with this continuity as it stimulated the oxygen flow. After approximately 20 minutes the fur of 416 the deer began to char and after 50 minutes the muscles in the hind legs began to contract.

417 After 1.5 hours, logs were no longer added to the fire as the pyre had collapsed, only a small 418 fire remained and the addition of more fuel would not cause the carcass to reduce any more. 419 By the end of the experiment the surface temperature of the pyre site was still considerably 420 high. A small portion of the torso was left consisting of soft tissue, and a substantial amount 421 of calcinated bone mostly from the front and hind legs, as well as the skull also remained.

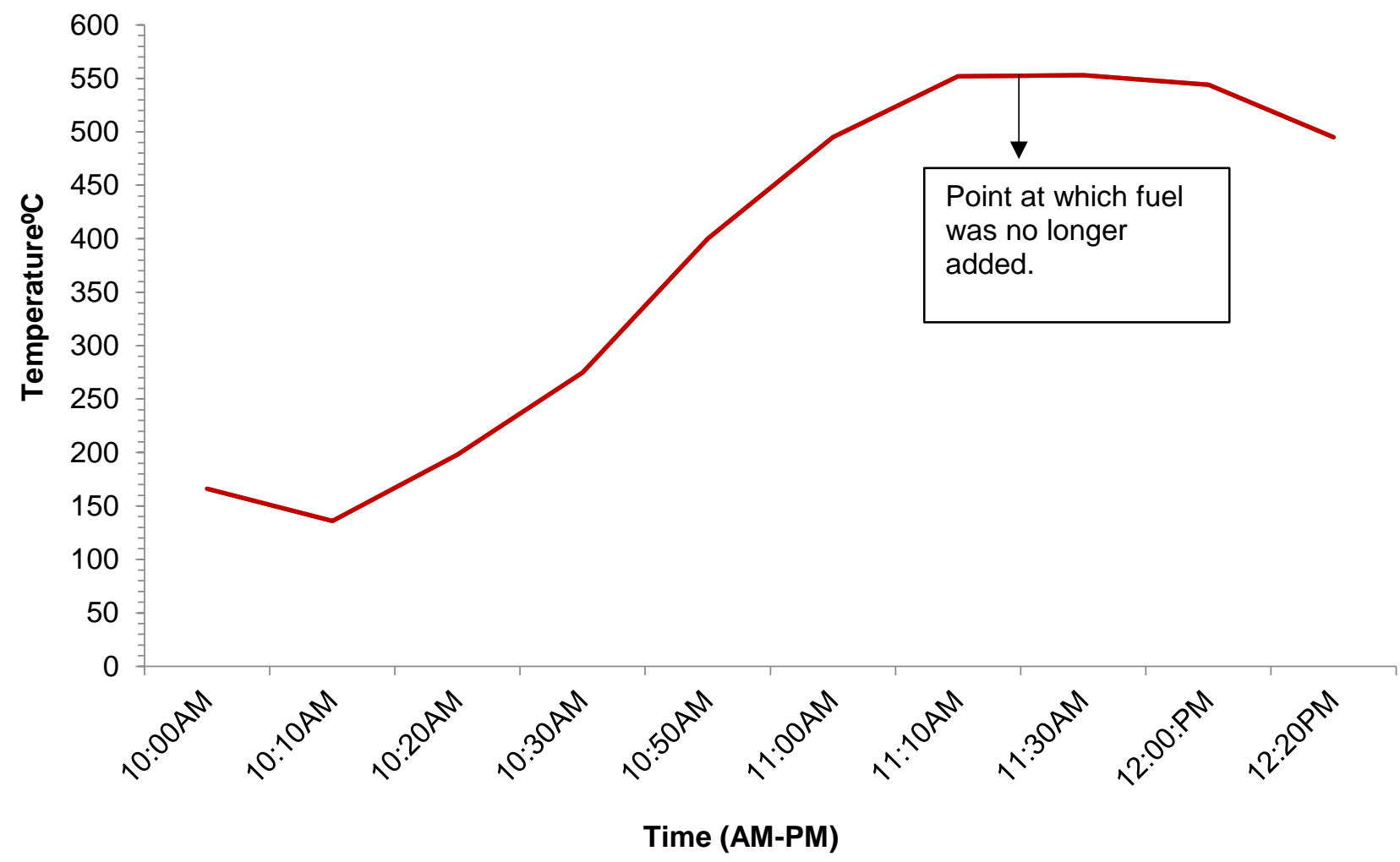

Fig. 10. The recorded temperatures of the funeral pyre over time. 


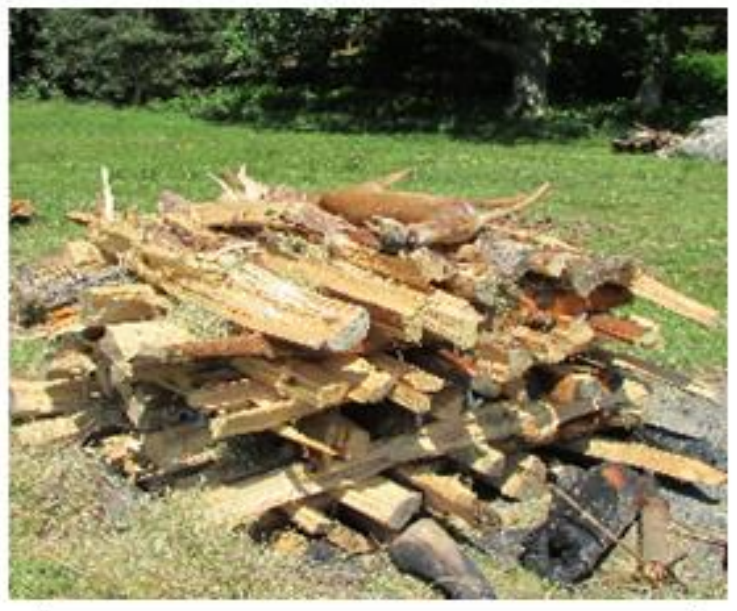

Set-up of carcass before combustion

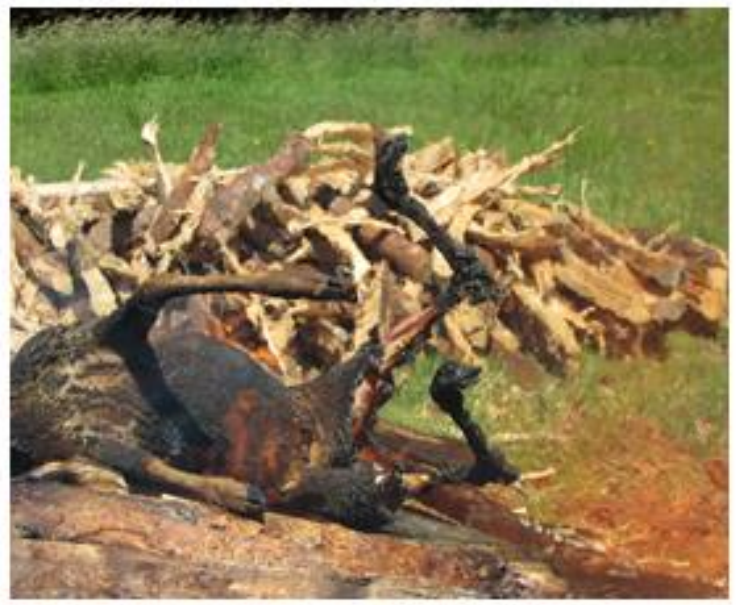

Flexing of carcass joints.
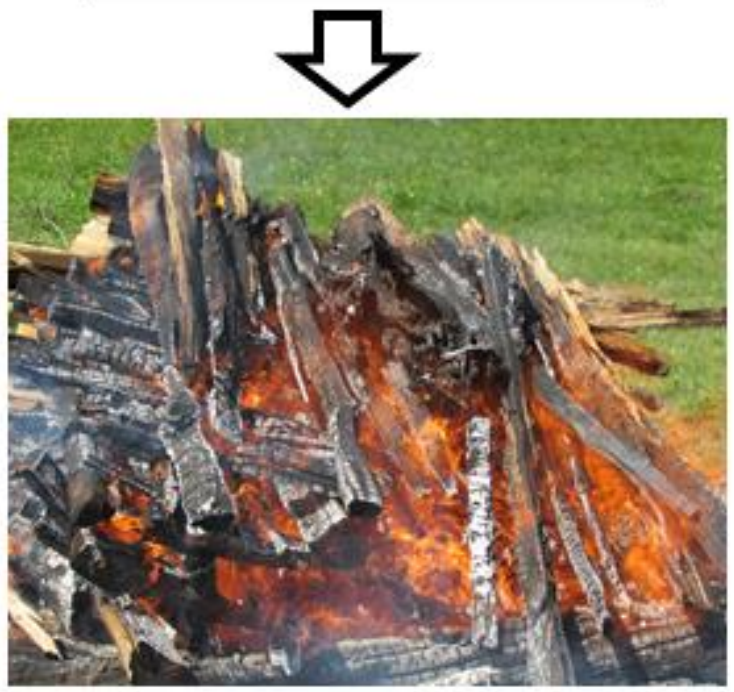

Collapse of pyre.

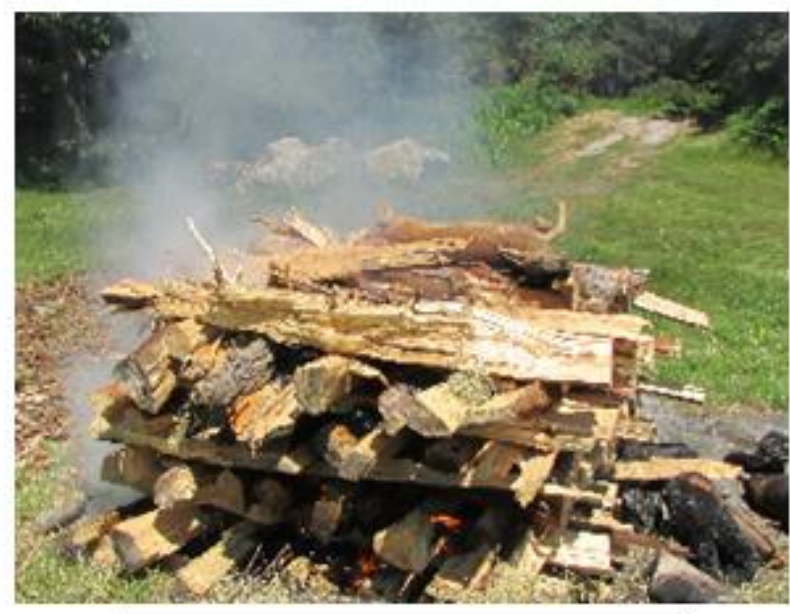

Initial combustion.
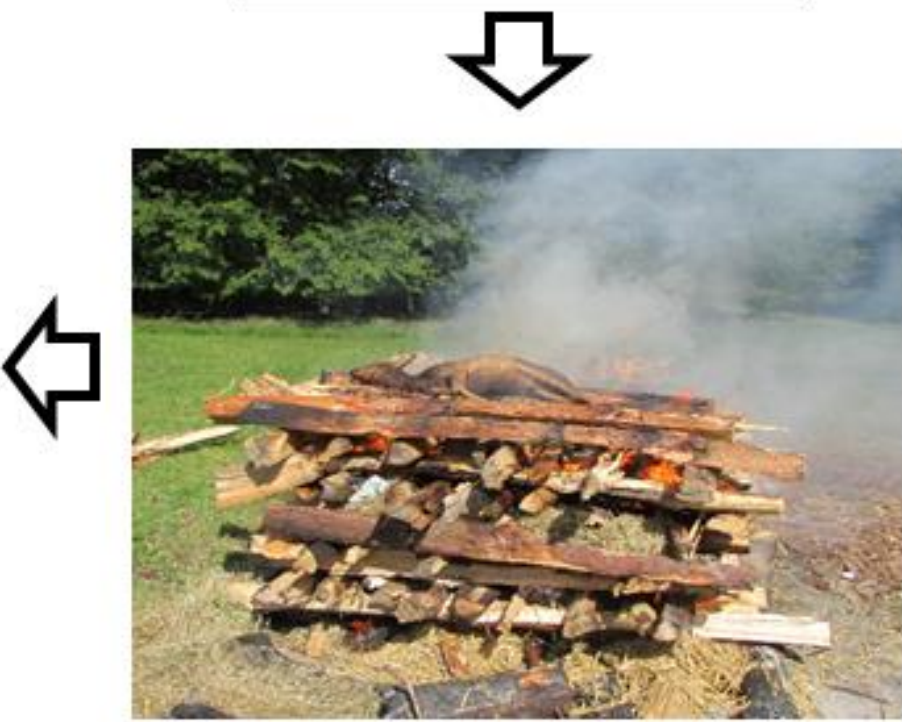

Charring of carcass.

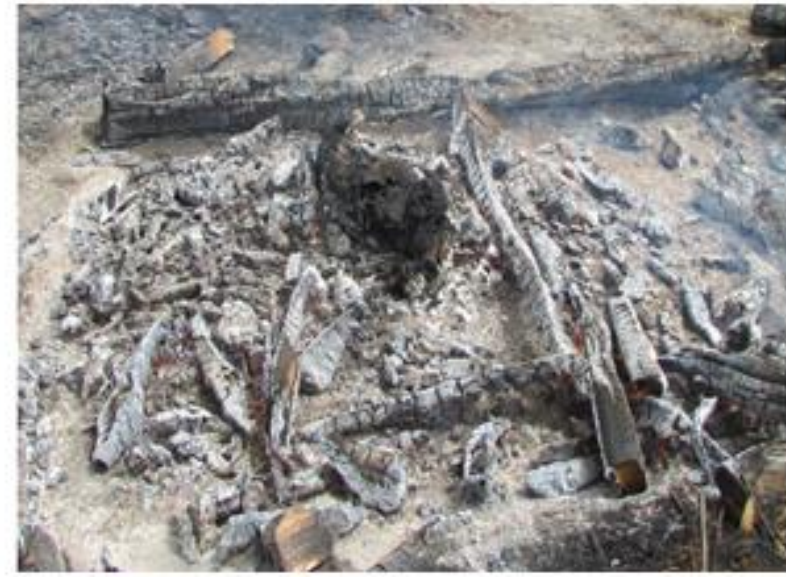

End of the experiment.

Fig.11. Flow diagram documenting the funeral pyre experiment. 


\subsection{Weight}

The shipping container fire produced 303 fragments of burnt material, including bone and soft tissue, weighing $699.23 \mathrm{~g}$ in total. The male deer carcass originally weighed $25 \mathrm{Kg}$ prior to burning. A weight reduction of $24,300.77 \mathrm{~g}(97.2 \%)$ took place during firing. The funeral pyre experiment on the other had resulted in 398 fragments of burnt material weighing $269.47 \mathrm{~g}$ in total. The female deer carcass originally weighed $20 \mathrm{Kg}$ before the experiment. A weight reduction of $19,730.53 \mathrm{~g}(98.65 \%)$ had occurred. In both instances, a similar quantity of burnt material was produced for both the male and female deer cadavers, however the weight of the burnt material varied substantially caused by the variation in soft tissue preservation. A students t-test found the difference in the average total weight to be significant $(p<0.000)$.

\subsection{Degree of Burning}

Figure 12 presents the results of the degree of burning from the two experiments. Of the 303 fragments recovered from the shipping container fire, the majority (184 fragments, 60.8\%) displayed a variety of stages of thermal decomposition, from no burning through to more than $50 \%$ carbonization, while the remainder (119 fragments, $39.2 \%$ ) exhibited more than $50 \%$ calcination. Overall the median score was 4 , with an interquartile range of 2 . The 398 fragments of bone from the funeral pyre however, exhibited a higher degree of calcination overall (367 fragments, 92.2\%) with only some evidence of carbonization through to calcination (31 fragments, $7.8 \%$ ) achieving a median value of 5 with an interquartile range of 0 . The Mann-Whitney $U$ test found this differentiation between the two datasets significant to $(p<0.001)$.

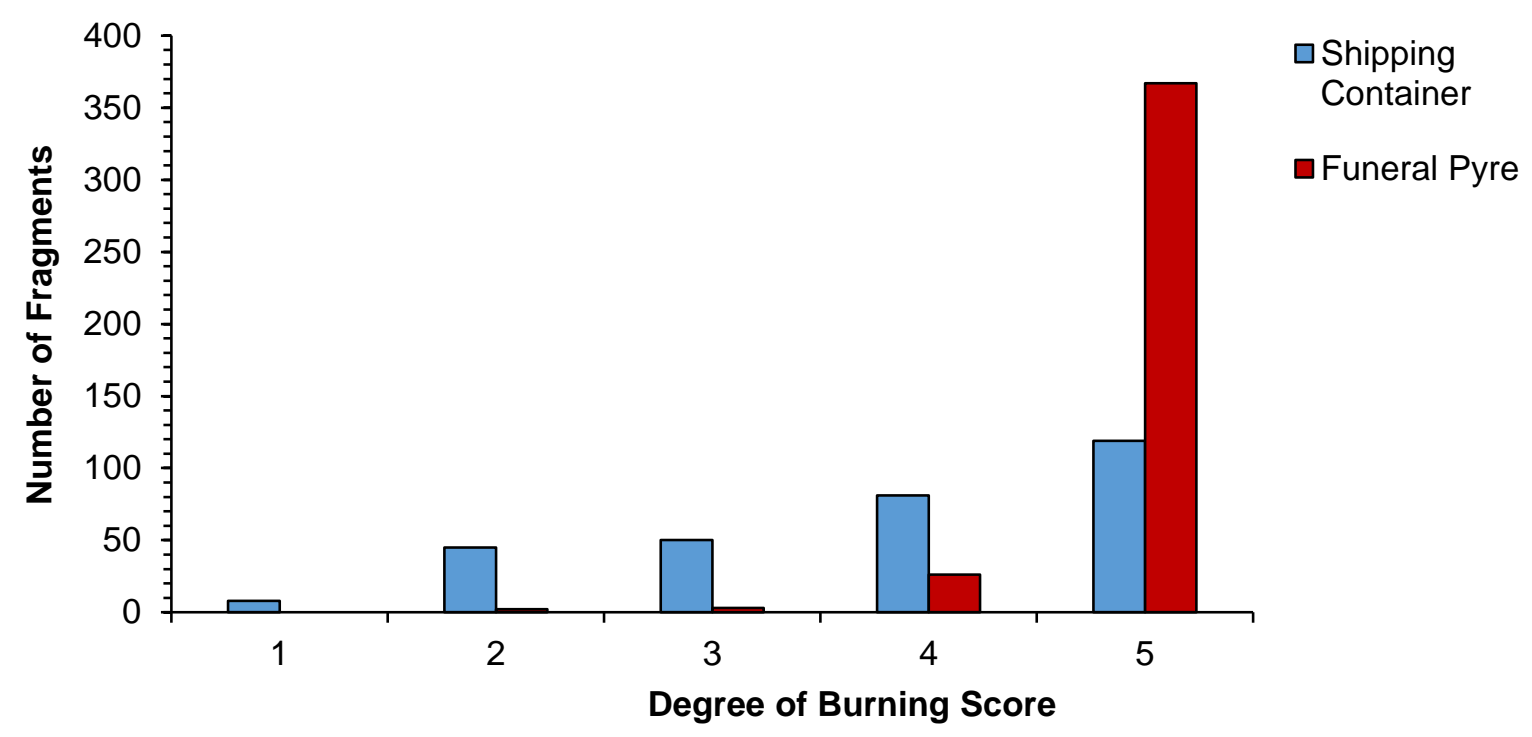




\subsection{Uniformity of Burning}

A similar outcome was also observed in the uniformity of burning (Fig 13). The fragments from the shipping container displayed varying levels of heat exposure with the majority (137 fragments, $45.2 \%$ ) exhibiting three different burning patterns on the same element and scoring a median value of 3 , with an interquartile range of 1 . However, over half of the fragments from the funeral pyre displayed a uniform burning pattern (290 fragments, $72.8 \%$ scoring 1 complete uniformity) while the remainder scored between two patterns of burning and four patterns of burning (108 fragments, 26.4\%), obtaining a median value of 1 and an interquartile range of 1 . Again, the difference between the two experiments were found significant by the Mann-Whitney $U$ test $(p<0.001)$.

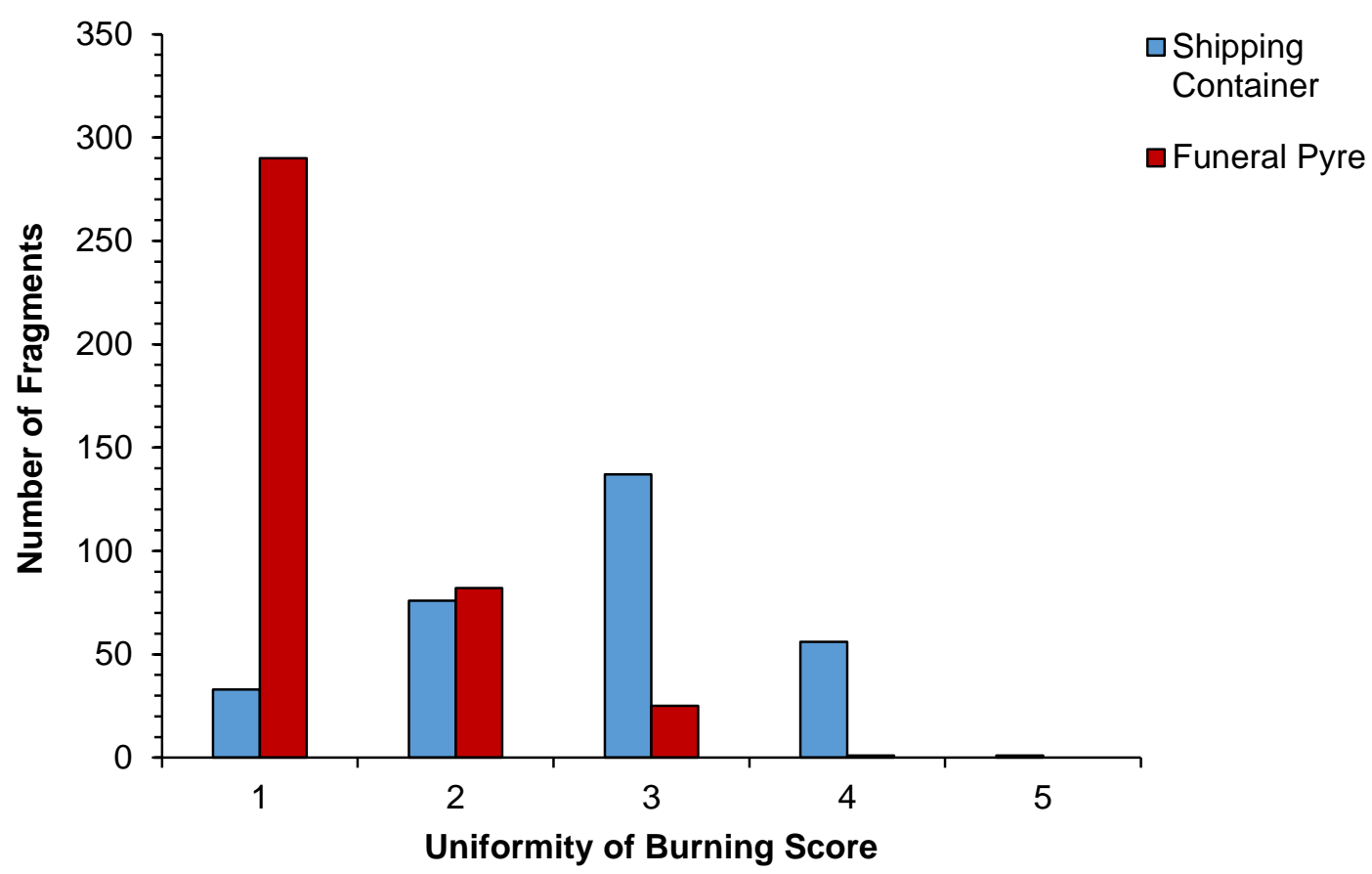

Fig. 13. The number of fragments scored for the uniformity of burning from the shipping 


\section{4.6. Colour Change}

476 The change in colour between the two datasets was also found to differ significantly (Fig 14), 477 with $\mathrm{P}<0.001$ obtained by the Mann-Whitney $U$ test. Score 6 (white colouration) was the most 478 observed pigmentation in both assemblages and was recorded 225 times (74.3\%) for the 479 shipping container and 389 times (97.7\%) for the funeral pyre; however the number of scores 480 in the other categories varied substantially between the two assemblages. The remaining 481 fragments from the shipping container demonstrated a relatively even spread of colouration 482 from brown to orange, while those from the funeral pyre displayed minimal variation and an 483 overall majority of white pigmentation.

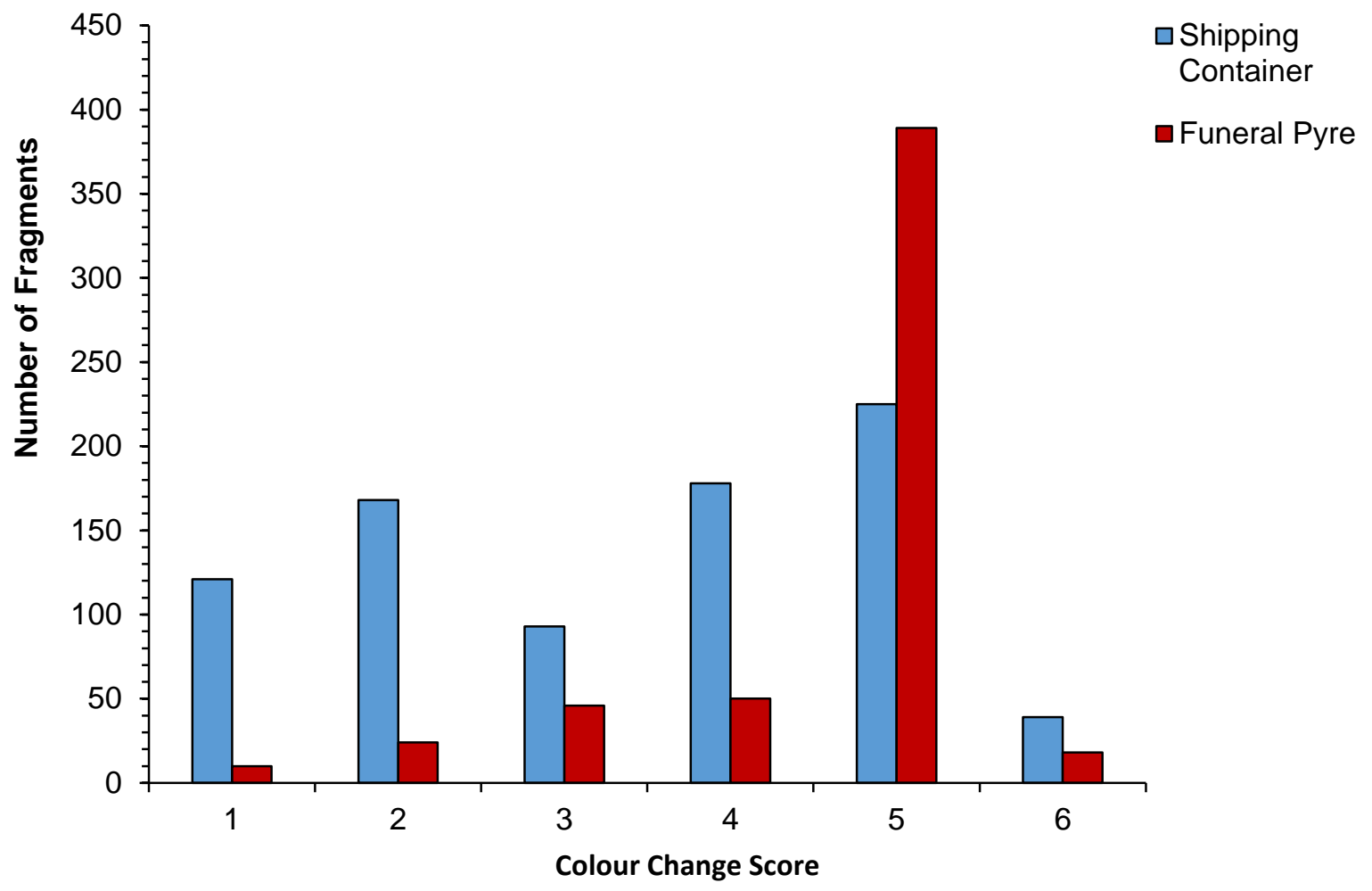

Fig. 14. The number of fragments scored for colour change from the shipping container and funeral pyre. 


\subsection{Fracture Patterning}

493 Only a small proportion of both assemblages exhibited fracture patterning. The results 494 presented in figure 15 show that the fragments from the shipping container consisted of mostly 495 longitudinal fractures (58 fragments, 19.1\%), with some transverse (3 fragments, 0.9\%) and 496 exfoliated patterning (23 fragments, 7.5\%), however polygonal breakages were not recorded. 497 The majority of fragments from the funeral pyre exhibited transverse fracturing (55 fragments, 498 13.8\%), with some evidence for longitudinal (11 fragments, $2.7 \%$ ) and polygonal breakages 499 (13 fragments, 3.2\%), but exfoliated fracturing was not evident. This differentiation was 500 significant by Mann-Whitney $U$ test $(p<0.001)$.

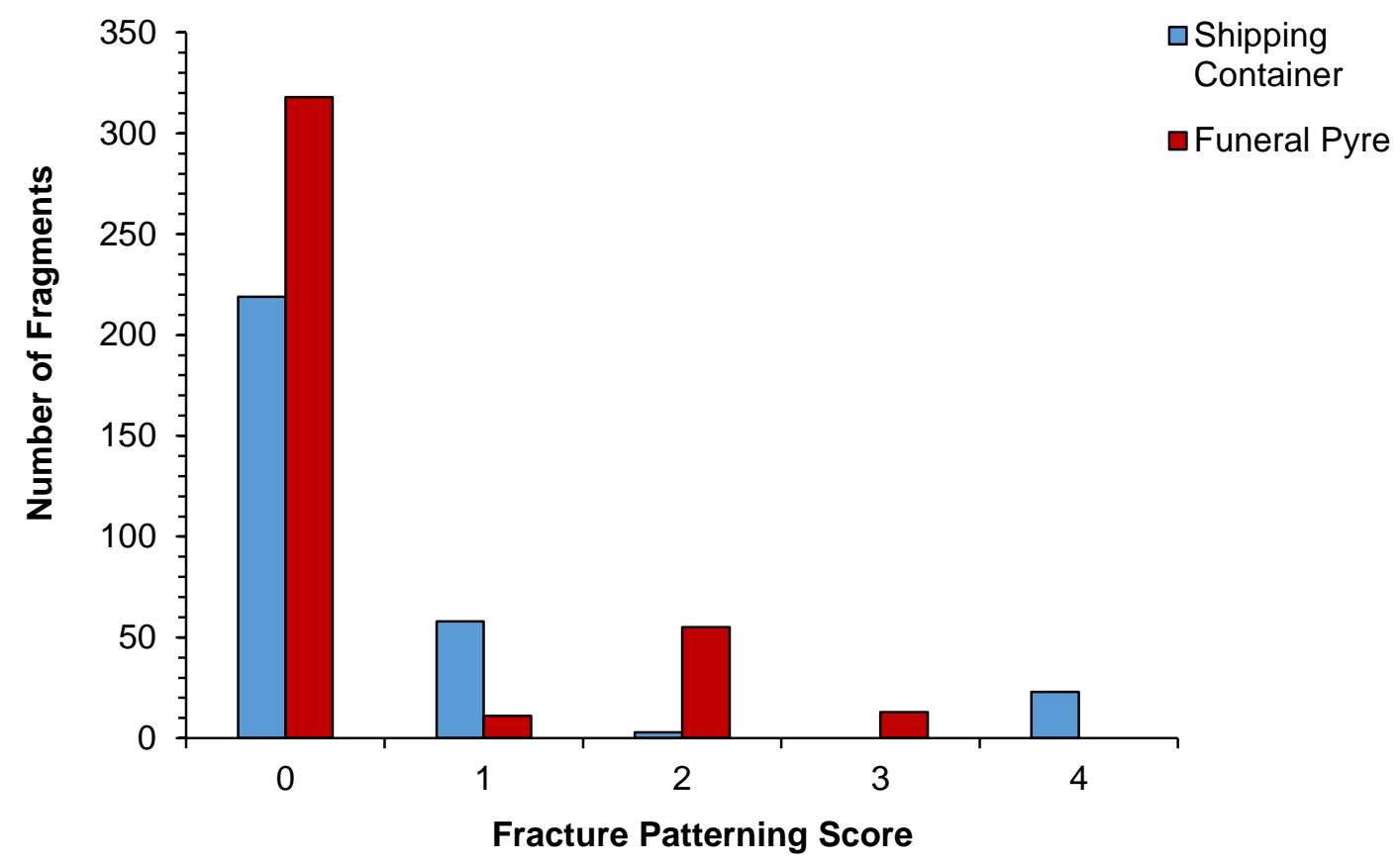

501

502 Fig. 15. The number of fragments scored for fracture patterning from the shipping container 503 and funeral pyre. 


\section{Discussion}

512 The use of field experiments in the burning of animal cadavers to investigate the macroscopic

$513 \mathrm{H}-\mathrm{I}$ modifications in burnt bone is a valuable scientific approach, as demonstrated by this

514 study, and should be applied more widely in this field of research to compliment laboratory

515 research. From this pilot study, it is clear that the use of fire within a non-laboratory

516 environment is challenging and warrants considerable effort and planning for all those

517 involved. The methodological approach provided in this study not only describes the resources

518 needed for conducting these types of experiments, including landowner's permission,

519 collaboration with the local fire authorities, and health and safety considerations, but also the

520 quantity and type of material needed to achieve a fires flash point and maintain combustion to

521 ensure the decomposition of a carcass. It also highlights key issues that should be taken into

522 consideration when planning such an experiment, including carcass storage to avoid

523 scavenging, the use of seasoned wood, and the difficulties surrounding recording the

524 temperature of the carcass itself.

525

526 Recently burnt bone is difficult to handle and transport back to a laboratory for analysis without

527 causing further post-burning damage. The material from the funeral pyre experiment was left

528 to cool for an hour before being sprayed with water. This action was taken to avoid leaving the

529 material overnight and risk scavenging. However, it is possible that this increased the risk of

530 bone fragmentation, considering the friable nature of the material. A small amount of bone

531 was initially tested, to establish whether this would compromise structural integrity. Seemingly,

532 no further breakage occurred. The material was left to dry before it was retrieved, however

533 this is not to say that fragmentation did not take place during transport as a result. The

534 quantification of $\mathrm{H}-\mathrm{I}$ modifications can also be challenging. By assessing every fragment and

535 using schematic scoring systems to document the $\mathrm{H}-\mathrm{I}$ modifications, a large amount of data

536 can be collected efficiently. These scoring systems are however subject to the perceptions of

537 the examiner; it would have been useful to conduct an inter-observer study of the methods

538 used in this paper to assess their reliability.

539

540 The value of this pilot study is the documentation of open-aired experimentation, and 541 recognition of the many aspects that need to be considered for sufficient and thorough 542 interpretation of the data. This is because the fires in this study were subject to multiple 543 influencing factors, including varying weather conditions, availability, quality and quantity of 544 fuel, the use of different sized and sexed carcass, and the simulation of accidental and 545 deliberate fires. Future research would benefit from measuring these conditions in greater 546 detail. 
548 These two opposing experiments, a deliberate funeral pyre and a simulated accidental house fire demonstrate how different ways of managing both the body and the fire can significantly affect the $\mathrm{H}-\mathrm{I}$ changes in bone. The burnt material from the funeral pyre demonstrates a predominately white colouration of uniformed burning. This has been observed in other pyre experiments as well as modern crematoriums (McKinley 1993; Schultz et al. 2015) and is most definitely a result of a consistent burn caused by the continual management of the fire, supplementation of the fuel load and a sufficient oxygen supply (David 1990). It is worth noting that other laboratory and field experiments have only achieved this level of calcination at temperatures in excess of $645^{\circ} \mathrm{C}$ (Shipman et al. 1984). The use of a non-contact digital LCD infrared thermometer that records temperature with an infrared beam directed at the pyre may not be the most accurate tool, despite being the safest. It would be useful for future research to find a way of measuring the temperature of the carcass and not just the fire. A small amount of soft tissue remained on the torso of the deer burnt on the funeral pyre. The torso is the last portion of the body to become skeletonised (Bohnert et al. 1998) and despite the continual management of the pyre and supplementation of the fuel, it was difficult to decompose.

The material recovered from the shipping container retained a lot of soft tissue, and demonstrated the full spectrum of colour alteration of inconsistent burning. These results have also been observed in both archaeological and modern fires (Bohnert et al. 1997; Noy 2000). It is in part due to different areas of the body consisting of greater proportions of soft tissue, and therefore requiring more extensive burning. Consequently, if burning conditions are inconsistent in relation to temperature, fuel and oxygen, and are not managed, complete thermal decomposition of the entire body will not be achieved (Schultz et al. 2015).

Despite both experiments producing similar quantities of material, the total weight differed, while the total average weight of individual fragments also varied significantly. This is due to the difference in the preservation of soft tissue between the two assemblages. Different types of fracture patterns were also observed in both assemblages. These results have also been observed in archaeological research (Thompson et al. 2016) and could simply be a reflection of the different ways in which these fires were managed. It would be interesting for future research to also examine the difference in fragmentation, as a means of exploring how the management of the body and manipulation of the fire can affect the breaking up of the material.

Both carcasses demonstrated joint flexure. It is unclear to what extent joint flexure is influenced by the condition of the animal when burnt, for instance time since death or extent of deposition. Even though the deer were culled three days before the experiment, they were 
kept in chest freezers in order to postpone decomposition, which may have enabled normal muscle contraction. However, the funeral pyre experiment was postponed for two days. As such, the carcass was stored on site in a metal container, which would have led to some degree of decomposition. It would be interesting for this aspect to be taken further with additional experimentation.

The observations made and the evidence collected from this study has enhanced our knowledge of burned human remains from both forensic and archaeological contexts. The combustion from the simulated house fire was intense, but short lived following the rapid depletion of the fuel load. From an archaeological perspective, it is clear that the spread of such a combustion through an organic dwelling would make it difficult to bring under control, extinguish or escape from; resulting in considerable stress and trauma for all those associated with that household. The fire from the funeral pyre was visually impressive and needed consistent management for a long period of time to sustain thermal combustion. Attending mourners would have witnessed the transformation of the body, creating a spiritual and ritual experience. However, the proceedings would have been laboursome and may have distinguished high status individuals who could afford such rites; for instance in the Roman empire a well burned body was considered ready for burial while a poorly fired cremation would lead to a restless soul (Lindsay 2000). Understanding this funerary process enhances our grasp of the ritual significance of cremation in the ancient world.

\section{Conclusion}

This paper has demonstrated the value of field experimentation and how it can complement the already extensive laboratory research available in this field. The documentation of openair field experiments is necessary for enhancing our knowledge of burned human remains. Organising and conducting field experiments is difficult, where conditions cannot be easily controlled. However, it does provide insight into the many different stimuli that can influence both managed and accidental fires. The results of this study have confirmed that two different open-air experiments produce significantly different rates of $\mathrm{H}-\mathrm{I}$ changes in skeletal remains, with regards to degree and uniformity of burning as well as fracture patterning, colour change and weight. This pilot study has also raised additional research questions concerning the preservation of a body and its effect on muscle contraction, as well as how to effectively record the temperature of a carcass during firing, all of which would benefit from the implementation of further field experimentation. 


\section{Acknowledgments}

620 The authors would like to thank Dr Gundula Müldner (Reading University) and Professor Rick

621 Stafford (Bournemouth University) for advice on statistics and manuscript preparation. We are

622 grateful to Terri Rees, Kevin Pickering and colleagues at West Moors Fire Training Centre,

623 Dorset, for assisting with the simulated house fire. Thanks also to the Sturdy family and 624 maintenance staff at Trigon Estate, Wareham Dorset for hosting and assisting with the 625 experimental pyre. The burnt bone analysis was conducted by the first author in the School of 626 Science and Technology at Bournemouth University.

\section{8. References}

628 Baby, R.S., 1954. Hopewell cremation practices. Papers in Archaeology. Ohio Historical 629 Society. Columbus, 1-7.

630 Bankoff, H.A., Winter, F.A., 1979. A house-burning in Serbia: What do burned remains tell an 631 archaeologist. Archaeology. 32, 5, 8-14.

632 Barillo, D.J., Goode, R., 1996. Fire fatality study: demographics of fire victims. Burns. 22, 2, 633 85-88.

634 Bennett, J.L., 1999. Thermal alteration of buried bone. Journal of Archaeological Science. 26, $6351,1-8$.

636 Binford, L.R., 1963. An analysis of cremations from three Michigan sites. Wisconsin 637 Archaeologist. 44, 98-110.

638 Bohnert, M., Rost, T., Faller-Marquardt, M., Ropohl, D., Pollak, S., 1997. Fractures of the base 639 of the skull in charred bodies: Post-mortem heat injuries or signs of mechanical 640 traumatisation? Forensic Science International. 87, 55-62.

641 Bohnert, M., Rost, T., Pollack, S., 1998. The degree of destruction of human bodies in relation 642 to the duration of fire. Forensic Science International. 95, 11-21.

643 Bond, J.M., Worley F.L., 2006. Companions in death: The roles of animals in Anglo-Saxon 644 and Viking cremation rituals in Britain. In Gowland, R., Knüsel, C., (Eds). Social archaeology 645 of funerary remains. Oxford, Oxbow, 89-98.

646 Brady, K., 2006. The prehistoric landscape at Tutt Hill, Westwell, Kent. CTRL Integrated Site 647 Report Series. London and Continental Railways. London.

648 Brickley, M.B., 2007. A case of disposal of a body through burning and recent advances in the 649 study of burned human remains. In Brickley, M., Ferllini, R., (Eds). Forensic Anthropology: 650 Case Studies from Europe. Charles C Thomas. Springfield, 69-85.

651 Buikstra, J.E., Swegle, M., 1989. Bone modification due to burning: Experimental evidence. In 652 Bonnichsen, R., Sorg, H., (Eds). Bone modification. Thompson-Shore Inc. Dexter, 247-258. 
653 Cain, C.R., 2005. Using burned animal bone to look at middle Stone Age occupation and 654 behaviour. Journal of Archaeological Science. 32, 6, 873-884.

655 Chalmer, B.J., 1987. Understanding statistics. Marcel Dekker. New York.

656 Collier, P.C.R., 1996. Fire in a residential building: Comparisons between experimental data 657 and a fire zone model. Fire Technology. 32, 3, 195-218.

658 Collini, F., Amadasi, A., Mazzucchi, A., Porta, D., Regazzola, V.L., Garofalo, P., Di Blasio, A. 659 and Cattaneo, C., 2015. The erratic behavior of lesions in burnt bone. Journal of Forensic 660 Science. 60, 5, 1290-1294.

661 David, B., 1990. How was this bone burnt? In Solomon, S., Davidson, I., Watson, D., (Eds). 662 Problem solving in taphonomy: Archaeological and palaeontological studies from Europe, 663 Africa and Oceania, Tempus, Archaeology and material culture studies in Anthropology. Vol 664 2. University of Queensland. Queensland, 65-79.

665 Dehaan, J.D., 2015. Fire and Bodies. In Schmidt, C.W., (Eds). The analysis of burned human 666 remains. $2^{\text {nd }}$ ed. Academic Press. Oxford, 1-16.

667 Delvin, J.B., Herrmann, N.P., 2015. Bone colour. In Schimdt, C.W., Symes, S.A., (Eds). The 668 analysis of burned human remains. $2^{\text {nd }}$ ed. Academic Press. Oxford, 119-138.

669 Downes, J., 1999. Cremation: a Spectacle and a Journey. In Downes, J., and Pollard, T., 670 (Eds). The Loved Body's Corruption. Archaeological Contributions to the Study of Human 671 Mortality. Cruithne. Glasgow, 19-29.

672 Dupras, T.L., Schultz, J.J., 2013. Taphonomic bone staining and colour change in forensic 673 contexts. In Pokines, J.T., Symes, S.A., (Eds). Manual of Forensic Taphonomy. CRC Press. 674 London, 315-340.

675 Ellingham, S.T.D., Thompson, T.J.U., Islam, M., 2015a. Estimating temperature exposure of 676 burnt bone - A methodological review. Science and Justice. 55, 181-188.

677 Ellingham, S.T.D., Thompson, T.J.U., Islam, M., 2015b. Thermogravimetric analysis of 678 property changes and weight loss in incinerated bone. Palaeogeography, Palaeoeclimatology, 679 Palaeoecology. 438, 239-244.

680 Ellingham, S.T.D., Thompson, T.J.U., Islam, M., 2016. The effect of soft tissue on temperature 681 estimation from burnt bone using fourier transform infrared spectroscopy. Journal of Forensic 682 Sciences. 61, 1, 153-159.

683 Etxeberria, F., 1994. Aspectos macroscópicos del hueso sometido al fuego: revisión de las 684 cremaciones descritas en el País Vasco desde la arqueologia. Munibe. 46, 111-116.

685 Field, A., 2009. Discovering statistics using SPSS. $3^{\text {rd }}$ ed. SAGE Publications Ltd. London.

686 Flamman, J.P., 2004.Two burnt-down houses examined. EuroREA. 1, 93-102.

687 Gonçalves, D. 2011. The reliability of osteometric techniques for the sex determination of 688 burned human skeletal remains. Homo-Journal of Comparative Human Biology. 62, 351-358. 
689 Gonçalves, D., Campanacho, V., Thompson, T., Mataloto, R., 2015a. The weight of the matter:

690 Examining the potential of skeletal weight for the bioarchaeological analysis of cremation at 691 the Iron Age necropolis of Tera (Portugal). In Thompson, T., (Ed). The archaeology of 692 cremation. Burned human remains in funerary studies. Oxbow Books. Oxford, 63-96.

693 Gonçalves, D., Cunha, E., Thompson, T.J.U., 2015b. Estimation of the pre-burning condition 694 of human remains in forensic contexts. International Journal of Legal Medicine. 129, 5, 11376951143.

696 Gonçalves, D., Thompson, T.J.U., Cunha, E., 2011. Implications of heat-induced changes in 697 bone on the interpretation of funerary behaviour and practice. Journal of Archaeological 698 Science. 38, 1308-1313.

699 Gruchy, S., Rogers, T.L., 2002. Identifying chop marks on cremated bone: A preliminary 700 study. Journal of Forensic Science. 47, 5, 1-4.

701 Harvig, L., Kveiborg, J., Lynnerup, N., 2015. Death in flames: Human remains from a domestic house fire from early Iron Age, Denmark. International Journal of Osteoarchaeology. 25, 701710.

Herrmann, N.P., Bennett, J.L., 1999. The differentiation of traumatic and heat-related fractures in burned bone. Journal of Forensic Science. 44, 3, 461-469. Jonuks, T., Konsa, M., 2007. The revival of prehistoric burial practices: Three archaeological experiments. Folklore. 37, 91-100.

Lindsay, H., 2000. 'Death-pollution and funerals in the city of Rome'. In Hope, V.M., Marshall, E., (Eds). Death and disease in the ancient city. Routledge. London, 152-173. Marciniak, S.M., 2009. A preliminary assessment of the identification of saw marks on burned bone. Journal of Forensic Sciences. 54, 4, 779-785.

Marshall, A., 2011. Experimental Archaeology: 1. Early Bronze Age cremation pyres 2. Iron Age Grain Storage. BAR British Series 530. Archaeopress. Oxford. Mayne Correia, P.M., 1997. Fire modification: A review of the literature. In Haglund, W.D.,

715 Sorg, M.H., (Eds). Forensic taphonomy: The post-mortem fate of human remains. CRC Press. 716 New York, 275-293.

717 McKinley, J.I., 1993. Cremated bone. In Timby, J., (Ed). Sancton I Anglo-Saxon cemetery 718 excavations carried out between 1976-1980. The Archaeological Journal. 150, 243-365.

719 McKinley, J.I., 1997. Bronze Age barrows and funerary rites and rituals of cremation. 720 Proceedings of the Prehistoric Society. 63, 129-145.

721 McKinley, J.I., 2004. The Anglo-Saxon cemetery at Sponge Hill, North Elsham Part VIII: The cremations. East Anglian Archaeology. EAA 69. Norfolk Museum Services. Norfolk.

723 McKinley, J.I., 2015. Forward. In Thompson, T., (Ed). The archaeology of cremation. Burned 724 human remains in funerary studies. Oxbow Books. Oxford, Vii-Xi. 
Nelson, R., 1992. A microscopic comparison of fresh and burned bone. Journal of Forensic Science. 37, 1055-1060.

727 Noy, D., 2000. Half-burnt on an emergency Pyre: Roman cremations which went wrong. 728 Greece \& Rome. 47, 2, 186-196.

729 Piga, G., Gonçalves, D., Thompson, T. J. U., Brunetti, A., Enzo, S., Malgosa, A. 2016. The advantage of combining ATR-IR and XRD analyses of burned skeletal remains for the estimation of maximum temperature. International Journal of Spectroscopy. DOI: http://dx.doi.org/10.1155/2016/481014.

Piga, G., Thompson, T., Malgosa, A., Enzo, S., 2009. The potential of X-Ray diffraction in the analysis of burned remains from forensic contexts. Journal of Forensic Sciences. 54, 534-539. Pope, E.J., Smith, O.C., 2004. Identification of traumatic injury in burned cranial bone: An experimental approach. Journal of Forensic Science. 49, 3, 431-440.

Poppa, P., Porta, D., Gibelli, D., Mazzucchi, A., Brandone, A., Grandi, M., Cattaneo, C., 2011. Detection of blunt, sharp force and gunshot lesions on burnt remains: a cautionary note. The American Journal of Forensic Medicine and Pathology. 32, 3, 275-279.

Rasmussen, M., Grønnow, B., 2004. The historical-archaeological experimental centre at Lejre, Denmark: 30 years of experimenting with the past. In Stone, P.G., Planel, P.G., (Eds). The Constructed Past. Experimental archaeology, education and the public. Routledge. London, 136.

Reidsma, F.H., Hoesel, A.v., Os, B.J.H.v, Megens, L., Braadbaart, F. 2016. Charred bone: Physical and chemical changes during laboratory simulated heating under reducing conditions and its relevance for the study of fire use in archaeology. Journal of Archaeological Science, 10, 282-292.

Ritchie, K., 2006. The prehistoric settlement at Little Stock Farm, Mersham, Kent. CTRL Integrated Site Report Series. London and Continental Railways. London. Salter, J. 2008. Male model murdered in a case of mistaken identity. The Telegraph. $8^{\text {th }}$ 751 August.

752 Schultz, J.J., Warren, M.W., Krigbaum, J.S., 2015. Analysis of human cremains. In Schmidt, 753 C.W., Symes, S.A., (Eds). The analysis of burned human remains. $2^{\text {nd }}$ ed. Academic Press. 754 Oxford, 83-103.

755 Shipman, P., Foster, G., Schoeninger, M., 1984. Burnt bones and teeth: An experimental study 756 of colour, morphology, crystal structure and shrinkage. Journal of Archaeological Science. 11, $757 \quad 4,307-325$.

758 Sigvallius, B., 1994. Funeral pyres. Iron Age cremations in North Spånga. Stockholm 759 University. Stockholm.

760 Silva, F.C., 2015. The funerary practice of cremation at Augusta Emerita (Mérida, Spain) 761 during high empire: Contributions from the anthropological analysis of burned human bone. In 
Schmidt, C.W., Symes, S.A., (Eds). The analysis of burned human remains. $2^{\text {nd }}$ ed. Academic Press. Oxford, 124-150.

Snoeck, C., Schulting, R.J., Lee-thorp, J.A., Lebon, M., Zazzo, A., 2016. Impact of heating conditions on the carbon and oxygen isotope composition of calcined bone. Journal of Archaeological Science. 65, 32-43.

Spennemann, D.H.R., Colley, S.M., 1989. Fire in a Pit: The effects of burning on faunal remains. Archaeozoologia. 3, 51-64.

Squires, K.E., Thompson. T.J.U., Islam, M., Chamberlain. A. 2011. The application of histomorphometry and Fourier Transform Infrared Spectroscopy to the analysis of early AngloSaxon burned bone. Journal of Archaeological Science. 38, 2399-2409.

Stiner, M.C., Kuhn, S.L., Weiner, S., Bar-Yosef, O., 1995. Differential burning, recrystallization, and fragmentation of archaeological bone. Journal of Archaeological Science. 22, 223-237.

Symes, S., L'Abbé, E.N., Chapman, E.N., Wolff, I., Dirkmaat, D.C., 2012. Interpreting traumatic injury to bone in medicolegal investigations. In Dirkmaat, D.C., (Ed). A Companion to Forensic Anthropology. Wiley. Chichester, 340-389.

Symes, S.A., Rainwater, C.W., Chapman, E.N., Gipson, D.R., Piper, A.L., 2015. Patterned thermal destruction in a forensic setting. In Schmidt, C.W., Symes, S.A., (Eds). The analysis of burned human remains. ( $2^{\text {nd }}$ ed). Academic Press. Oxford, 17-60.

Thompson, T.J.U., 2005. Heat-induced dimensional changes in bone and their consequences for forensic anthropology. Journal of Forensic Science. 50, 1-8.

Thompson, T.J.U., Gauthier, M., Islam, M. 2009. The application of a new method of fourier transform infrared spectroscopy to the analysis of burnt bone. Journal of Archaeological Science, 36, 910-914.

Thompson, T.J.U., Islam, M., Bonniere, M., 2013. A new statistical approach for determining the crystallinity of heat-altered bone mineral from FTIR Spectra. Journal of Archaeological Science. 40, 416-422.

Thompson, T. J. U., Szigeti, J., Gowland, R. L., Witcher, R. E., 2016. Death on the frontier: military cremation practices in the north of Roman Britain. Journal of Archaeological Science. 10, 828-836.

Thurman, M.D., Willmore, L.J., 1982. A replicative cremation experiment. North American Archaeologist. 2, 4, 275-283.

Tipper, J., 2012. Experimental archaeology and fire: The investigation of a burnt reconstruction at West-Stow Anglo-Saxon village. East Anglian Archaeology 146. Archaeological Services. Suffolk County Council. Suffolk.

Ubelaker, D.H., 2009. The forensic evaluation of burned skeletal remains: A synthesis. Forensic Science International. 183, 1-5. 
799 Ullinger, J., Sheridan, S.G., 2015. Bone colour changes in burned burial structure from early 800 Bronze Age Baba dh-Dhra, Jordan. In Schimdt, C.W., Symes, S.A., (Eds). The analysis of 801 burned human remains. $2^{\text {nd }}$ ed. Academic Press. Oxford, 403-413.

802 Vasserol, A.R., Cunha, E., Batista de Carvalho, L.A.E., Gonçalvesm D., 2016. Rather yield 803 than break: Assessing the influence of human bone collagen content on heat-induced warping 804 through vibrational spectroscopy. International journal of Legal Medicine. 130, 6, 1647-1656.

805 Whyte, T., 2001. Distinguishing remains of human cremations from burned animal bones. 806 Journal of Field Archaeology. 28, 437-448.

807 Acts of Parliament:

808 Animals (Scientific Procedures) Act 1986. 